\title{
Enabling Technologies for Sector Coupling: A Review on the Role of Heat Pumps and Thermal Energy Storage
}

\author{
Omais Abdur Rehman ${ }^{1,2}$, Valeria Palomba ${ }^{1}$ (D) Andrea Frazzica ${ }^{1, *(D)}$ and Luisa F. Cabeza ${ }^{2}$ (D) \\ 1 Consiglio Nazionale delle Ricerche Istituto di Tecnologie Avanzate per l'Energia "Nicola Giordano", \\ CNR ITAE, 98126 Messina, Italy; rehman@itae.cnr.it (O.A.R.); valeria.palomba@itae.cnr.it (V.P.) \\ 2 GREiA Research Group, Universitat de Lleida, Pere de Cabrera s/n, 25001 Lleida, Spain; luisaf.cabeza@udl.cat \\ * Correspondence: andrea.frazzica@itae.cnr.it; Tel.: +39-090-624419
}

check for

updates

Citation: Abdur Rehman, O.;

Palomba, V.; Frazzica, A.; Cabeza, L.F. Enabling Technologies for Sector

Coupling: A Review on the Role of

Heat Pumps and Thermal Energy

Storage. Energies 2021, 14, 8195.

https://doi.org/10.3390/en14248195

Academic Editors: Antonio Rosato,

George Kosmadakis and Adrián

Mota Babiloni

Received: 21 September 2021

Accepted: 29 November 2021

Published: 7 December 2021

Publisher's Note: MDPI stays neutral with regard to jurisdictional claims in published maps and institutional affiliations.

Copyright: (c) 2021 by the authors. Licensee MDPI, Basel, Switzerland. This article is an open access article distributed under the terms and conditions of the Creative Commons Attribution (CC BY) license (https:// creativecommons.org/licenses/by/ $4.0 /)$.

\begin{abstract}
In order to reduce greenhouse gas emissions, current and future energy systems need to be made more efficient and sustainable. This change can be accomplished by increasing the penetration of renewable energy sources and using efficient technologies in energy generation systems. One way to improve the operation of the whole energy system is through the generation and end-use sector coupling. Power-to-heat energy conversion and storage technologies, in this view, are enabling technologies that can help in balancing and improving the efficiency of both thermal and electric grids. In the present paper, a comprehensive analysis of the role of heat pumps and thermal energy storage for sector coupling is presented. The main features of the analyzed technologies are presented in the context of smart electric grid, district heating and cooling and multi-carrier energy systems, and recent findings and developments are highlighted. Finally, the technical, social, and economic challenges in the adoption of investigated technologies are discussed.
\end{abstract}

Keywords: heat pumps; thermal energy storage; multi-carrier systems; energy systems; sector coupling

\section{Introduction}

Globally, electricity is mainly produced by fossil fuels, which lead to greenhouse gas emissions (GHG) [1]. To reduce the GHG emissions in the energy sector, high shares of renewable energy sources (RES) penetration are required in existing and future energy production systems. Upcoming energy infrastructures should make full use of RES available locally as it will help energy systems in bringing a sustainable green transition of the economy [2]. Moreover, it will also help in reducing the environmental impacts caused by the use of fossil fuels in energy production. Solar, wind, and hydro power are the main RES through which electric power can be generated. Nevertheless, $\mathrm{CO}_{2}$ emissions do not only come from electricity generation. Indeed, sectors including heating and cooling, transport, industry, and agriculture also cause relevant $\mathrm{CO}_{2}$ emissions. For instance, according to the International Energy Agency (IEA), the heating sector accounts for almost $50 \%$ of global energy use [3]. Therefore, a sustainable energy system requires the use of RES also for heating and cooling and, since the main output from RES generation is electricity, electricity, and heating sector coupling is of paramount importance [4]. Decarbonization strategies bring new challenges in terms of planning and operational activities but also provide opportunities for optimization across different energy sectors [5]. In a worldwide existing scenario, efficient heating and cooling technologies are needed to reduce greenhouse gas emissions, while some sort of storage mechanism is needed to reduce the supply and demand gap in the heating and electricity sectors. Both these sectors (heating/cooling and storage) can be electrified to achieve low carbon emissions goals. In turn, the sector coupling will also be beneficial for the power sector as it provides improved flexibility, reliability, and adequacy [6]. The transition from current energy systems to future sustainable 
systems also requires an approach based on the integration of various energy components and exploitation of synergies by sector integration [7].

Sector coupling, a synonym to sector integration and multi-carrier energy system (MCES), has recently gained increased attention [8]. The benefits of investing in one sector may spread to other sectors as all available energy sectors work in cooperation with each other. High expectations are associated with sector coupling in terms of decarbonization and a smooth green transition, but it is yet to be seen how and to what extent current technologies will be integrated for this purpose. Due to the wide use of current fossilbased technologies and lack of dynamic market-based price signals, the decarbonization of the heating and cooling sector is a bit difficult. Electrification of these sectors would provide low-cost solutions with a possibility to store energy in large-scale thermal energy storage systems [7]. Moreover, sector integration of electricity and heating can provide a cost-effective way for low-carbon energy systems with high penetration levels of RES. Such integration can mainly be achieved through the incorporation in thermal grids for district heating (district heating networks, DHNs) of enabling technologies for high RES deployment, easing the coupling with the smart grid. Two main challenges need to be tackled for a full deployment of RES in DHC: solutions to cover the gap between demand and supply and the use of systems to adjust temperature levels according to the distance between heat source and end-users. Among the various technical solutions available for the sector coupling of electricity and heat, heat pumps (HP), electric boilers, combined heat and power (CHP) plants and thermal energy storage (TES) can be used [9].

The main focus of this paper will be on HP and TES. It first discusses the latest status of HP and TES technologies that are mainly being employed in district heating and cooling (DHC). Moreover, both these technologies can play a significant role in the upcoming fifth generation of DHC. This generation will have ultra-low supply temperatures, which will help in reducing heat losses. HP, as mentioned in the work of [10-12], is among the possible technologies for the transition toward low-temperature and cooling-dominated district networks. In order to reduce the demand and supply gap, TES can be incorporated into DHC systems. It can work as a buffer between heat demand and supply and thus increases the reliability of energy supply. Moreover, it also provides flexibility to DH systems in order to integrate RES with them [13].

So far, the subject of enabling technologies for sector coupling has been analyzed, but it is mostly focused on specific cases and configurations or centered on single technologies, such as heat pumps only [14] or TES only [15]. Accordingly, the novelty of this paper lies in the fact that it extensively reviews the role of heat pumps and thermal energy storage technologies in the context of sector coupling of heating/cooling and electricity.

\section{What Is Sector Coupling?}

Sector coupling refers to the integration and interconnection of different end-users and supply energy sectors [7]. Until recently, energy networks have been considered separately, and only interventions for the optimization of a single network have been put in place. Sector coupling instead allows all present networks to be integrated into a comprehensive energy system usually defined as a multi-carrier energy system (MCES). An MCES consists of several energy carriers, e.g., heat, electricity, natural gas, hydrogen, etc., as shown in Figure 1 [16]. The benefits of combining various energy vectors are multiple; apart from economic and environmental aspects, sector coupling also allows for increased resilience of the energy system. For instance, a study conducted by Muhammad et al. [17] compared risk-averse and risk-seeking scenarios to evaluate the impact of MCES in the operation of unified gas, electricity, and DH networks. The paper concluded that MCES reduced the operating cost of the integrated system by 1.3\%. Moreover, MCES could reduce the influence of uncertainty in wind power production on operating costs by $20 \%$. In the risk-seeking scenario, the MCES technology allows the operator to implement its strategy under lower risk levels. In the risk-averse scenario, the operator can implement a strategy with a reliability $20 \%$ higher than in the risk-seeking approach. 


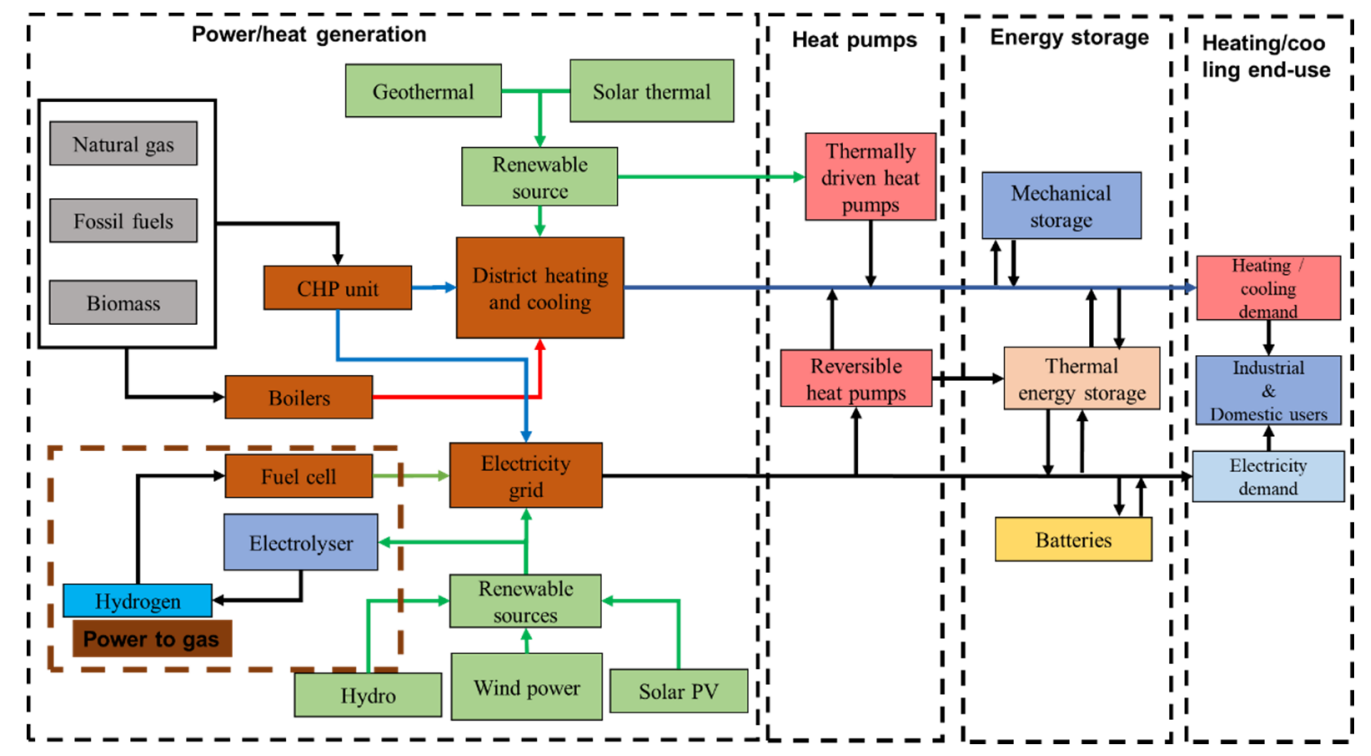

Figure 1. Concept of a multi-carrier energy system (MCES).

In MCES, energy carriers are connected and interrelated with the help of energy hubs $[18,19]$. An energy hub behaves like an interface between transmission setups and clients. It delivers energy to cover consumer needs [20]. In this type of system, thermal energy storage and heat pumps, which can act as energy conversion systems and even carrier-conversion systems, are crucial components, and their role for service provision to prosumers and the grids needs to be evaluated.

Among the different sector coupling combinations, the integration of electricity and heating sectors can assume a major role in decarbonization strategies. A part of this regulatory framework is the EU strategy for energy system integration [21], which advocates, among the measures in the path for climate neutrality by 2050, the transition from networks where different energy carriers were built and operated independently to a system where interconnected networks (gas, electricity, heat) are operated in strong synergy. This sector coupling is mainly made possible by technological advancements in the different networks, among which the wide deployment of combined heat and power, power-to-heat and distributed energy storage technologies, as well as smart management algorithms are included [22].

Within hybrid grids, the CHP concept is especially interesting since it already provides both energy carriers needed. A number of previous studies discuss the possibility of the power-to-heat concept, with some discussing combining heat pumps and CHP to balance renewable production [23-25]. Levihn [23] studied the combination of CHP and heat pumps via modeling. The research was performed based on a DH network in Stockholm, which has over 12 TWh annual heat demand. This study provided insights into the empirics and practical knowledge of CHP and HP operation. It was mentioned that heating and cooling demands serve as boundary conditions for HP operation. Moreover, it was observed that higher COP of HP reduces the sensitivity to electricity prices. Grohnheit [24] discussed the feasibility of modeling existing CHP powerplants to provide heat as well. The study explains that previously, only electricity was considered as an output of CHP in modeling approaches performed at the national level. This modeling was mainly carried out by commercial utilities and companies that were supposed to provide energy to consumers. The paper discusses short-term modeling based on days and weeks and long-term modeling based on a year. Another study found that the incremental cost to build a CHP compared to a single-purpose plant is usually minimal and lies in the range of 100-200 EUR/ $\mathrm{kW}$ [26]. Moreover, the combined production of heat and power leads to the overall efficiency of the plant as compared to the sole production of electricity only [25]. 
In the last decade, energy production from RES has seen a sharp rise. The energy supply from RES is often intermittent because it is weather dependent. So, the energy production from solar and wind power plants partly matches the electricity demand. Nevertheless, the generation of energy exceeds the demand during certain time durations in a day because of high input from RES $[27,28]$. This surplus energy should be used through a power-to-heat approach. The power-to-heat concept refers to the conversion of electricity to heat through heating resistors, electrode boilers, and heat pumps. Powerto-heat applications can better use the existing RES and can also make better use of the expanding renewable network. Temporary renewable surplus generation can be fed to power-to-heat, especially at the district level [29]. For instance, a study made in Denmark suggested that large-scale installation of heat pumps is the most important strategy for increasing the share of wind power in Danish primary energy consumption [30]. If active or passive thermal energy storage is available, the use of renewable overflows can even be used better [31-33].

Power-to-heat strategies can be applied at the centralized or decentralized level. A comparison of centralized and decentralized power-to-heat options in DH networks is shown in Figure 2. The DH approach is an example of centralized power to heat. Heat is produced centrally either with electric boilers [34] alone or in combination with large-scale heat pumps (ground sourced, waste heat, brine, etc.) [35]. In a centralized approach, energy is withdrawn from the grid for the generation of heat. Decentralized heat production accounts for the generation of heat at the residential level and does not involve the use of a heating network. Most of the power-to-heat options, both at centralized and decentralized levels, are associated with an energy storage mechanism.

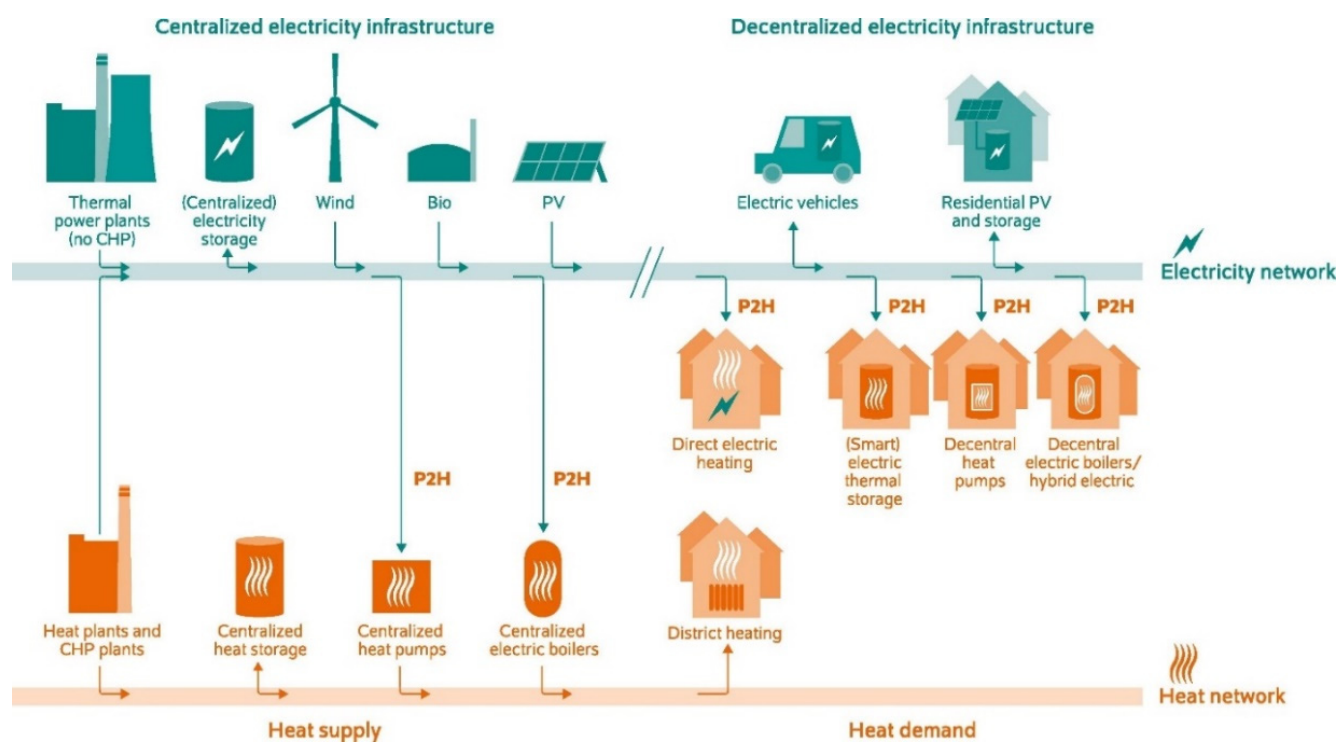

Figure 2. Linkage of power-to-heat options with DH networks and electricity [34].

\section{Thermal Grids: General Aspects}

Both HP and TES are currently being used extensively in DHC. So, before explaining their current status of employment in DHC and how they can be used in future scenarios for sector coupling, a brief discussion on main aspects related to existing and proposed DHC architectures has been presented below.

A thermal grid for district heating $(\mathrm{DH})$ is a system used for providing heat to consumers [36]. Heat is moved from production sources (boilers, combined heat and power (CHP), industrial waste heat, etc.) to sinks (consumers) through distribution networks. A typical DH system is shown in Figure 3. District heating and cooling (DHC) systems date back to several years, but they were not widely implemented in all countries. USA, Germany, and Russia were among those countries who developed DH systems initially [37,38]. 


\section{Residential and commercial}

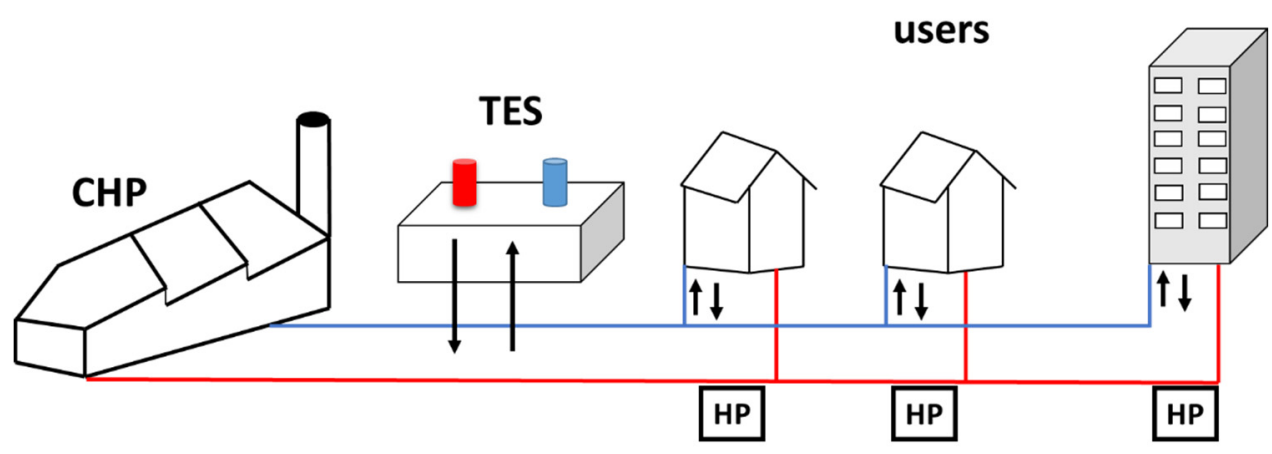

Figure 3. A traditional DH system supply line is red, while the return line is blue.

DH systems have evolved over time, changing from the first generation to the fifth generation, which has been recently proposed [14]. Initial DH generations used steam as a heat carrier in concrete pipes and temperatures above $200{ }^{\circ} \mathrm{C}$. The second-generation DH systems used pressurized hot water as a heat carrier with supply temperatures above $100{ }^{\circ} \mathrm{C}$. Large shell-tube heat exchangers were used along with material-intensive heavy valves. Second-generation DH systems prevailed till 1970, and then the third generation took on. In the third generation, pressurized water was used as a heat carrier, but supply temperatures fell below $100^{\circ} \mathrm{C}$. Pre-insulated fabricated pipes and substations with plate stainless steel heat exchangers were used underground to transport heat [39]. The new generation of $\mathrm{DH}$, i.e., the fourth generation $\mathrm{DH}$, supplied water at low temperatures $\left(45-60{ }^{\circ} \mathrm{C}\right)$ [40]. One of the main peculiarities that marked the evolution of DHC, which allows the sector coupling, is the radical change in the number and type of heat generation technologies used, passing from the first/second generation (steam boilers running on coal and CHP plants) to the third generation, which included the heat production from biomass, waste, fossil fuel boilers, along with large-scale and distributed CHP plants. Solar energy was also harnessed at a large scale to meet heating demands. Renewable sources were integrated into the fourth generation to a greater extent, and low-temperature heat recycling was also made available [39]. Solar photovoltaic (PV) and wind energy were brought in parallel with CHP plants for power production by connecting them with the electricity grid. Junca [41] found out that a grid-connected system needs lower initialinvestment costs as storage (battery banks, e.g.) is not required. Such a system can result in a $50 \%$ reduction in the total life cycle cost of installation. Seasonal TES using sensible heat technology was also incorporated in the fourth generation $\mathrm{DH}$ systems.

The latest and upcoming generation, i.e., the fifth generation, has 'prosumers' as end-users who will both consume and produce energy. The concept of the fifth generation is shown in Figure 4. Buffa et al. analyzed 40 different DHC network projects of the fifth generation, which are currently operational in Europe [14]. These are mainly pilot projects that will help to understand the economic and technical aspects of the fifth generation in real operation. These projects are being carried out in Italy, Switzerland, Netherlands, Belgium, England, and Norway. The fifth generation thermal grids for DHC also include some additional and unique features that require a paradigmatic shift in the technologies employed, especially at the building and neighborhood level. In particular, the temperature level of water in the supply lines is close to ground temperature, and therefore it is paramount to use efficient technologies such as heat pumps that can work as temperature boosters/adjusters. Finally, due to the massive introduction of different heat generation sources, among which several are renewables, it will be necessary to incorporate energy storage systems. 


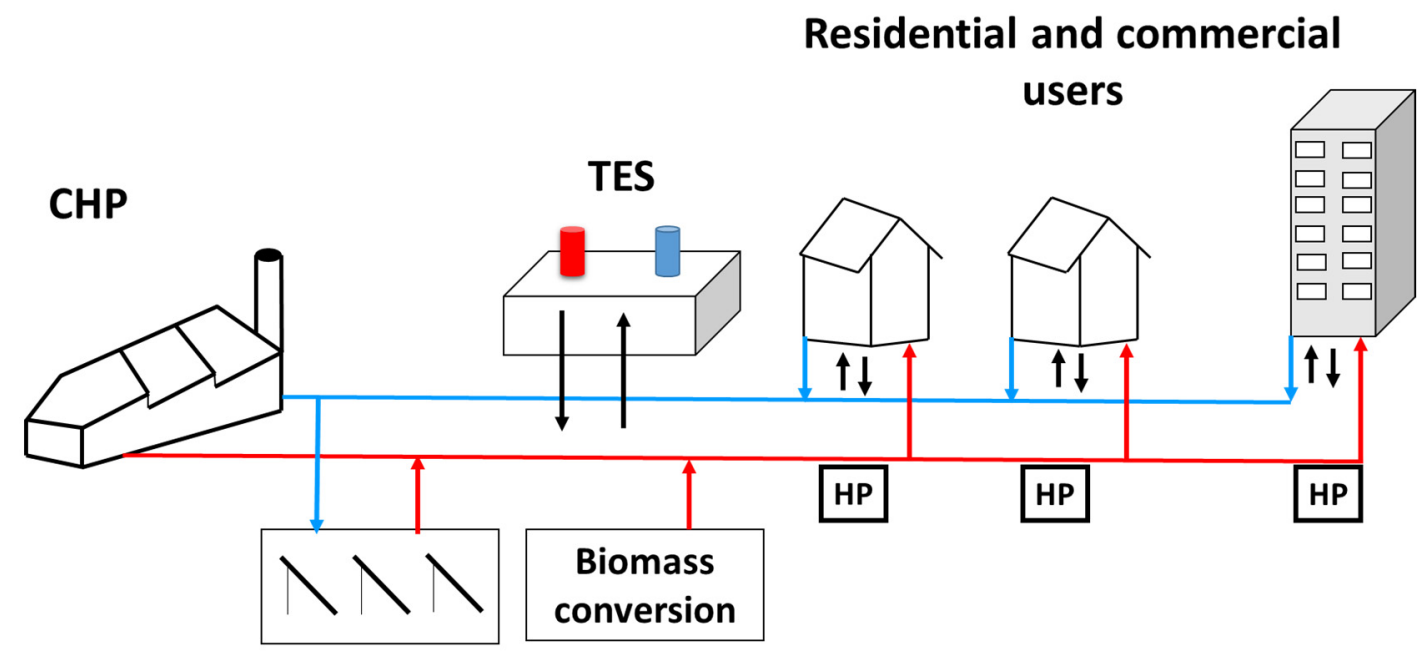

Large scale solar thermal

Figure 4. Fifth-generation DH system supply line is red while return line is blue. Arrows represent energy exchange. HP represents heat pumps.

A comparison of all generations of DH systems is given in Table 1, which allows identifying the main peculiarities of new generation DHC and their main differences from the previous cases.

Table 1. Features of DH generations [39,42].

\begin{tabular}{|c|c|c|c|c|c|}
\hline Features & 1st Generation & 2nd Generation & 3rd Generation & 4th Generation & 5th Generation \\
\hline Temperature & $>200{ }^{\circ} \mathrm{C}[11]$ & $>100{ }^{\circ} \mathrm{C}[11]$ & $<100{ }^{\circ} \mathrm{C}[11]$ & $45-60{ }^{\circ} \mathrm{C}[11]$ & $\begin{array}{l}\text { Region dependent, } \\
\text { close to ambient } \\
\text { temperature }\left(10-30{ }^{\circ} \mathrm{C}\right)\end{array}$ \\
\hline Energy sources & $\begin{array}{l}\text { Coal-fired boilers, } \\
\text { CHP [39] }\end{array}$ & $\begin{array}{c}\text { Coal- and } \\
\text { oil-based CHP } \\
{[39]}\end{array}$ & $\begin{array}{l}\text { Biomass, waste or } \\
\text { fossil fuel boilers, } \\
\text { CHP [39] }\end{array}$ & $\begin{array}{c}\text { Solar PV, wind } \\
\text { energy, } \\
\text { low-temperature } \\
\text { recycling [39] }\end{array}$ & $\begin{array}{c}\text { High penetration of } \\
\text { RES, heat pumps, } \\
\text { industrial surplus } \\
\text { heat [39] }\end{array}$ \\
\hline $\begin{array}{c}\text { Renewable energy } \\
\text { sources }\end{array}$ & No & No & Yes & Yes & Yes \\
\hline $\begin{array}{l}\text { Simultaneous } \\
\text { provision of heating } \\
\text { and cooling }\end{array}$ & No & No & No & No & Yes \\
\hline $\begin{array}{l}\text { Centralized/ } \\
\text { Decentralized }\end{array}$ & Centralized & Centralized & Centralized & $\begin{array}{c}\text { Partially } \\
\text { decentralized }\end{array}$ & Highly decentralized \\
\hline Heat carrier & Steam [11] & $\begin{array}{l}\text { Pressurized water } \\
{[11]}\end{array}$ & $\begin{array}{l}\text { Pressurized water } \\
{[11]}\end{array}$ & $\begin{array}{l}\text { Low-temperature } \\
\text { water [11] }\end{array}$ & $\begin{array}{l}\text { Ultra-low-temperature } \\
\text { water }\end{array}$ \\
\hline Prosumers & No & No & No & Yes & Yes \\
\hline $\begin{array}{l}\text { Period of available } \\
\text { technology }\end{array}$ & 1880-1930 [39] & 1930-1980 [39] & 1980-2020 [39] & 2020-2050 [39] & In research phase \\
\hline Thermal losses & High & High & Medium & Low & Very low \\
\hline Exergy losses & High & High & Medium & Low & Very low \\
\hline Thermal storage & No & No & No & Yes & Yes \\
\hline
\end{tabular}

\section{The Heat Pumps for Power-Thermal End-Use Sector Coupling}

\subsection{Generalities}

Heat pumps, when used in a controlled and appropriate way, can help ease the transition toward decentralized energy systems. Heat pumps are considered to be a low $\mathrm{CO}_{2}$ emission technology in the residential heating sector. Generally, electricity is used to drive low-exergy heat through a vapor compression cycle toward high temperature and high level of exergy [43]. 
In recent years, heat pumps have gained interest as an enabling technology for smart electric grids, becoming an enabling technology for sector coupling, converting renewable electricity into heating and cooling. Working fluid, which is a refrigerant, is used for delivering heating or cooling via a vapor compression cycle. Depending on the operation, useful effects can be extracted in the form of heat on the condenser side (i.e., space heating, domestic hot water) and cooling on the evaporator side (i.e., space cooling, refrigeration). On this topic, vast literature exists, and the most recent relevant studies are summarized in Table 2, mainly focusing on the benefits garnered by smart grids when HP are integrated. These can mainly be divided into the following domains:

- Supplying ancillary services for the grid (grid-driven); Heat pumps are employed in a grid to ensure that voltage remains within allowed limits [44]. Excessive load causes a decrease in voltage and vice versa. The voltage level often increases during daytime when electricity is being injected into the grid through solar PV. During times of overvoltage, the active power demand of heat pumps can be increased to keep the voltage within the allowed range while decreasing it during the low-voltage time period. Heat pumps also help in congestion management by reducing grid reinforcement, keeping the transformer load in pre-determined tolerance ranges $[45,46]$ through a switch on/off of heat pumps pools. Finally, HPs act as demand-side management units and can be used for responsive loads during times of imbalances in the grid [47,48]. For such reserves, a mechanism has been developed in the electricity market, which helps in deciding which units to use. In most countries, a minimum limit has been set to participate in the reserve market (e.g., $5 \mathrm{MW}$ in Germany and $10 \mathrm{MW}$ in northern European countries). So, a pool of heat pumps is needed in order to take part in a reserve market. Such projects have been mentioned in the references [49-51]; however, on-field examples are limited and need deeper understanding [44,52];

- Enabling integration of power through RES at building, grid, or power system level (renewable energy-driven); As far as wind power is concerned, it was shown that it can be integrated with variable speed heat pumps at the building level and the required electricity from the grid can be reduced up to 95\% $[53,54]$. At grid level, as wind power plants are installed with a capacity of over $1 \mathrm{MW}$, a large number of HP would be needed to use the generated electricity. It has been shown that such a pool of HP, being controlled in an optimal way, helps in absorbing the electricity generated from wind power and thus assists in reducing the need for peak capacity [43]. Hedegaard and Münster studied the influence of heat pumps in reducing the need for peak capacity investments of 300-600 MW, corresponding to the size of a large powerplant [30]. They concluded that the integration of HP in large wind power systems can facilitate in reducing system costs, fuel consumption, and carbon emissions. They also mentioned that HP, along with individual heat storage, contributes significantly to peak load shaving. For optimal operation of heat pumps, an external signal is required containing electricity prices or real-time wind power production, which helps in adjusting the operation of heat pumps. Another effect of a wide deployment of heat pumps is linked to the fact that, for the last few years, locally generated PV electricity has become cheaper, thus going toward decentralized generation. In this view, the main advantage of heat pumps is the possibility to fully adapt to a demand-response approach if combined with real-time information. For instance, PV generation, upon exceeding a threshold, can switch on the heat pump's operation, thus increasing the use ratio of locally produced electricity from $30 \%$ to over $65 \%$ [55]. Finally, with the help of heat pumps, reduction in feed-in peaks in the grid are reported in the range of 30-55\% [56,57];

- Operating under fluctuating electricity prices (price-driven); One of the features that make the electrification of the heating and cooling sector interesting from an economic point of view is that energy costs can be saved by taking advantage of low prices in the day-ahead market and additional revenues can be earned in the balancing market [58]. Indeed, electricity prices keep fluctuating on day to day basis 
(day-ahead pricing) or even throughout a day (real-time pricing). A predictive model or a scheduling algorithm is needed that considers the load profile and electricity prices in order to guarantee a smooth and cost-efficient operation of heat pumps. Different price schemes were applied in studies that included prices of electricity that remain static for a long time [59-62] or fluctuate after short intervals [31,63-65]. The aim is to minimize the annual cost of energy. Most studies focused on decentralized control and reported significant load shifting using price signals. Moreover, savings were reported ranging from $7 \%$ up to around $35 \%[66,67]$. Studies were carried out on how to control the working of HP when electricity prices are known ahead of time. Having such a schedule of electricity prices leads toward the operation of HP during night time, since prices are low at that period of time. It should be noted that the operation of an HP at variable times based on 'reducing cost of energy' may cause a decrease in its efficiency. The reduction in efficiency can be mainly because of higher storage temperature, lower external temperatures during operation, and enhanced part-load ratios [43].

Table 2. Summary of the role of heat pumps in smart electricity grids.

\begin{tabular}{|c|c|c|c|}
\hline Application & Aim & Findings & References \\
\hline \multirow{3}{*}{ Ancillary services for grid } & Voltage control & $\begin{array}{l}\text { Voltage problems can be reduced with } \\
\text { the appropriate controlling strategies } \\
\text { of HP. }\end{array}$ & \multirow{3}{*}[44-52,59,68-71]{} \\
\hline & Congestion management & $\begin{array}{c}\text { Grid reinforcement can be reduced. } \\
\text { Control strategies can reduce peaks but } \\
\text { not in all cases. } \\
\text { HP operation shows strong seasonal } \\
\text { dependency for grid services. }\end{array}$ & \\
\hline & $\begin{array}{l}\text { Balancing generation demand } \\
\text { and frequency regulation }\end{array}$ & $\begin{array}{c}\text { Pools of HP can be used. } \\
\text { On-field examples are limited. }\end{array}$ & \\
\hline \multirow[b]{2}{*}{ Integration of RES } & PV & $\begin{array}{l}\text { Self-consumption increases with the } \\
\text { use of variable speed HP. } \\
\text { Seasonal inconsistency affects } \\
\text { self-consumption. } \\
\text { Feed-in peaks at noon can be reduced. }\end{array}$ & \multirow[b]{2}{*}[30,53-57]{} \\
\hline & Wind & $\begin{array}{l}\text { Wind integration reduces carbon } \\
\text { emissions. } \\
\text { It also helps in reducing fluctuations } \\
\text { and peaks. } \\
\text { Use of grid electricity can be reduced } \\
\text { with local wind turbines. }\end{array}$ & \\
\hline Price-driven operation & Fluctuating electricity prices & $\begin{array}{l}\text { More focus on decentralized control. } \\
\text { Significant load shifting reported using } \\
\text { price signals. } \\
\text { Negative effect on efficiency reported. }\end{array}$ & {$[31,43,58,61-67]$} \\
\hline
\end{tabular}

\subsection{Application of Heat Pumps in DHC}

As already stated, the latest studies are focusing on fifth generation DHC networks, which, compared to the previous ones, can be considered neutral from the perspective of thermal losses since the temperature of supplied water is close to the ground one. In this case, to reach the temperature levels needed by the users (i.e., for heating/cooling and domestic hot water (DHW)), the water at lower temperatures (in the range of 0 to $30^{\circ} \mathrm{C}$ ) is supplied to "local adjustors", which operate according to the demand. Reversible heat pumps can be a beneficial technology in the context of local adjustors as they have the capability to work in both heating and cooling modes [72]. Localized heat generation via 
heat pumps can then greatly reduce the thermal losses in the grid. Different uses of heat pumps in a DH network for coupling of different sources and sinks are shown in Figure 5.

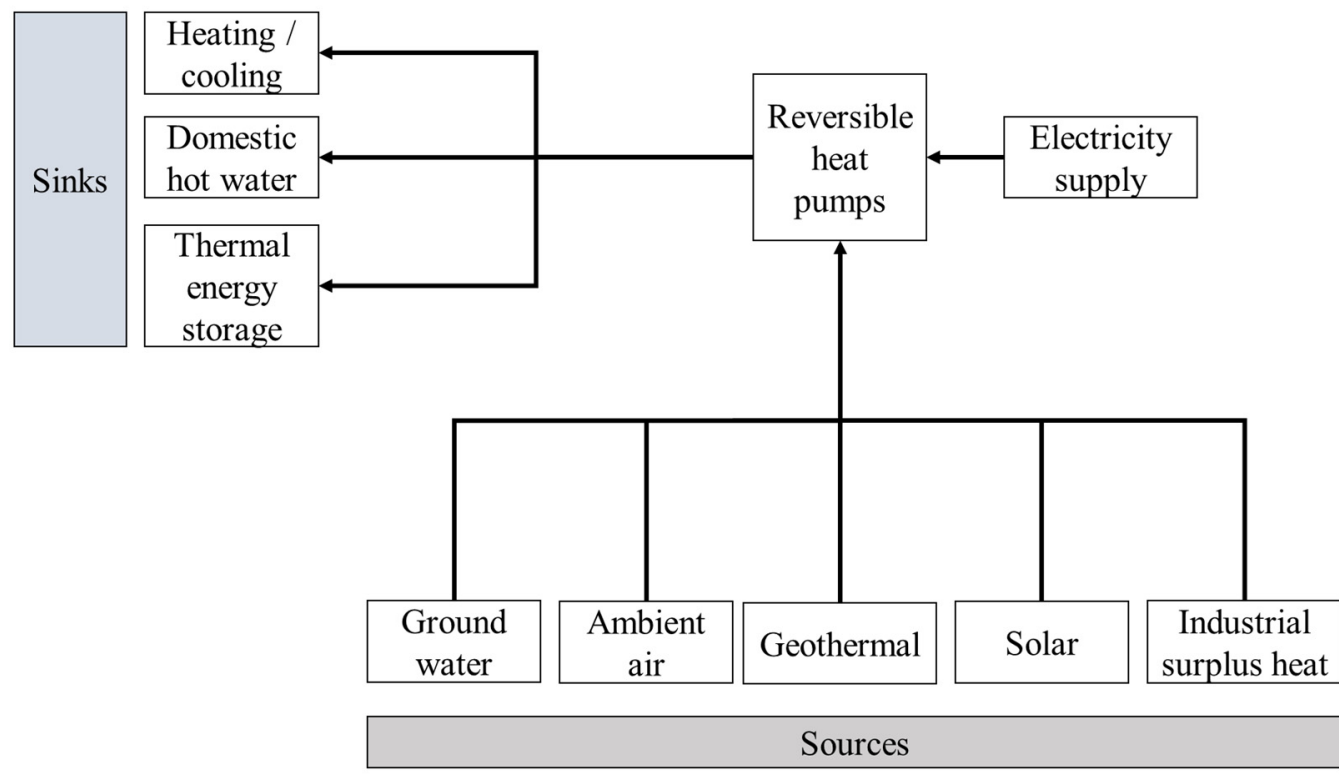

Figure 5. Operation of heat pumps with typical heat sources and sinks of DHC.

Having heat pumps in DH networks will also help in the decarbonization of the energy system. According to Chen et al. [73], significant emissions reduction, in the range of 30-40\%, were noticed in Beijing based on a scenario when heat pumps partially replaced coal boilers. Similarly, a study carried out in New York City by Waite and Modi concluded that $10 \% \mathrm{CO}_{2}$ emissions reduction were noted when heat pumps replaced $20 \%$ of gas-fired boilers [74]. Heat pumps along with thermal energy storage are considered to be a valuable combination as they will help in further combating greenhouse gas emissions. An analysis carried out in Finland considering future (2035) and present scenarios regarding fulfilling the heating demand of users indicated that $30 \%$ emissions reduction can be achieved in future scenarios with the use of heat pumps, thermal energy storage, and electrical boilers [33].

The technical characteristics of heat pumps used at the district level (up to now mainly for heating purposes) are shown in Figure 6 [75].

\subsection{Heat Pumps as Enabling Technology for Sector Coupling}

In the previous sections, the main benefits and features for the application of HPs within the smart electric grid and the new generation DHC were discussed. However, sector coupling requires a true integration between the two types of grids through synergistic actions. This section discusses the barriers still existing in incorporating HP as connectors of the electric and thermal grid, along with policy measures that need to be taken to boost the use of HP.

From the technical point of view, one of the main challenges is the placement of heat pumps in existing networks (second or third generation DHC) [75], due to the high temperature levels of the network and the lack of suitable sources (geothermal, solar). A common solution can be to place heat pumps either at the existing central heat source (CHP or electrical boilers) or at a local heat source [75]. Heat pumps will work alongside the existing heat source in a multi-source mode. This connection can be made either parallel or series, and both sources will work with different shares of thermal capacity. CHP or boiler can be made to work at lower part-load ratios, and load can be adjusted with HP. In order to investigate such working performance of HP and CHPs, modeling of energy systems is needed. Felten presented an integrated model for sector coupling of heat and electricity for 
large-scale energy systems [76]. The technologies considered for modeling sector coupling include CHP, electric boilers, HP, heat-only boilers, and thermal energy storage. It was concluded that such modeling techniques help a lot to take future measures related to energy policies, curbing greenhouse gas emissions, supporting RES schemes while also lending a great help in analyzing power systems and assessing investment valuation.

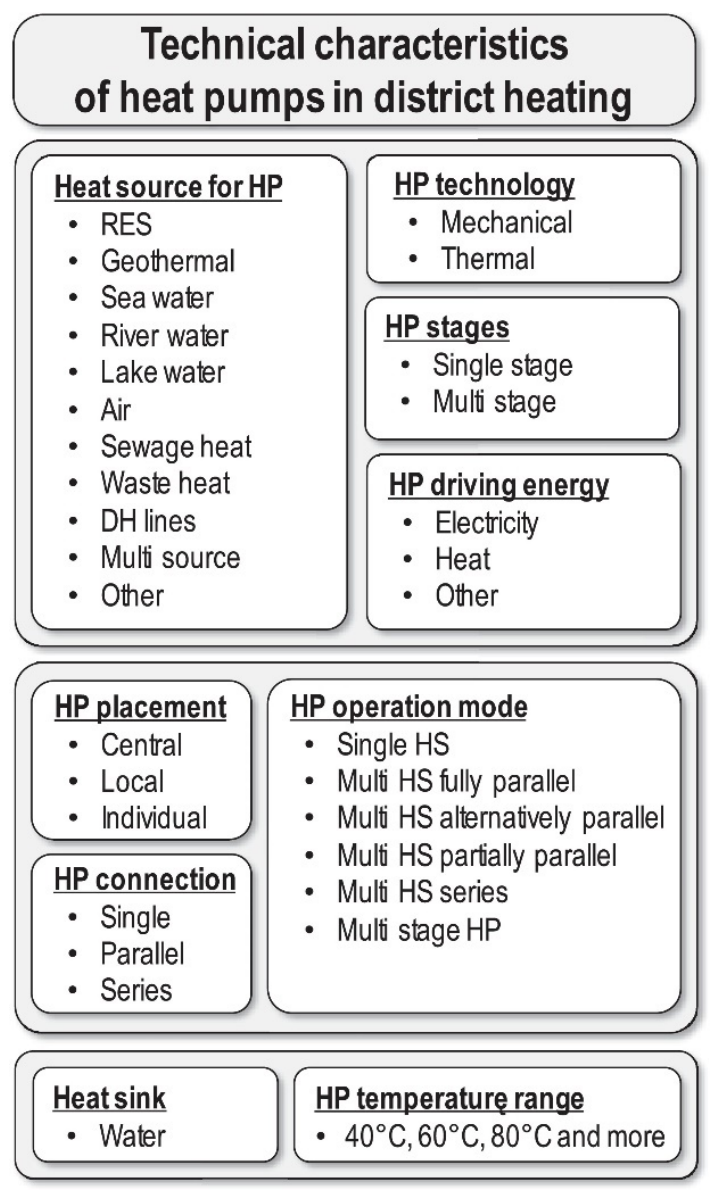

Figure 6. Technical characteristics of heat pumps in district heating [75].

Existing thermal grids are operating at high temperatures, which makes the integration of HP difficult and unfeasible. In upcoming thermal grids, it is possible to define the temperature level that suits the range where HP is more efficient [77]. Moreover, through suitable exergo-economic models [78-80] or dynamic simulations [81,82], it is possible to define the main parameters for the selection of heat pumps features within hybrid thermal-electric grids, mentioned below and also shown in Figure 7 [83]:

- Heat source;

- Heat pump technology, i.e., the connection, sizing, and operating mode of the heat pump;

- Heating demand, which is linked to the need for a demand-response approach.

Ground source HP, which has a suitable potential as a low-exergy heating system, gained considerable attention from researchers because of its highly effective use of electricity and suitable use of low-temperature sources [78]. Meesenburg et al. [79] made an exergo-economic analysis of a heat pump in an integrated energy system. The focus of the study was to integrate a heating and power system with a ground source heat pump. It was mentioned that coupling of the above-mentioned sectors provides feasibility to decouple the electricity demand and supply. Moreover, it also provides a balancing service to the power grid. The used operation strategy takes into account the heat demand and power regulations. It was concluded that providing demand flexibility leads to higher exergy destruction. Barone et al. [82] made a dynamic simulation for thermo-economic analysis as 
well as optimization of DH systems containing heat pumps / chillers. The developed simulation tool assesses and optimizes the energy, environment, and economic performance of a DH system. Optimization of system design and operating parameters is also achieved through dynamic modeling. Another aspect to be taken into account is the presence of adequate infrastructure for sector coupling, which is currently hindering the wide adoption of HP [84]. For instance, decentralized heat generation may result in frequent run-and-stop times, which should instead be avoided through suitable control logic [55]. Furthermore, there is a need for the digitalization of such a hybrid thermal-electric network in order to optimize the interaction and transaction processes at the local level where heat pumps have been employed. Indeed, whereas in the past, the inter-communication between the supply and end-use sections was complex, the use of advanced controlling techniques through artificial intelligence for appropriate use of HP technology [85] has strongly reduced such an issue. It is worth considering that in the majority of available studies, the heat pump has been treated as a black box, with no specific consideration for the particular operating conditions within the thermal and electric grids. On the contrary, the design of the whole heat pump should be investigated according to the requirements for specific grid applications.

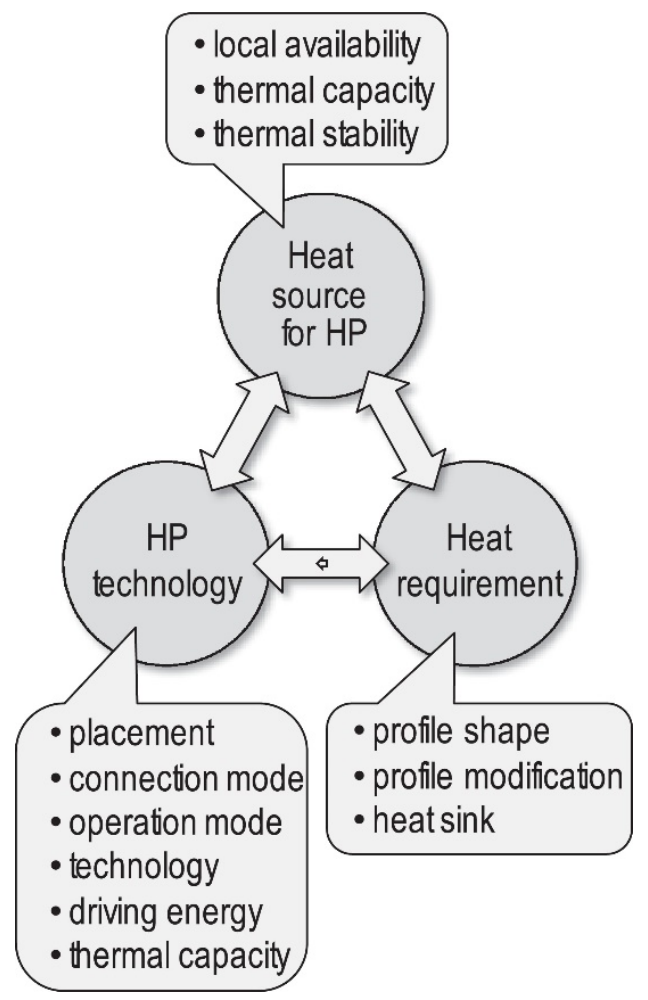

Figure 7. Technical triangle featuring key features for integrating heat pumps in DH [75].

Apart from the technical considerations, the economic aspects are still the major barrier to be considered when discussing sector coupling. In principle, the price-driven operation of HP should be advantageous since electric boilers can be used when the price is very low, while HPs can operate over a broader spectrum of electricity prices because of their high efficiencies. However, current heating technologies, such as oil, gas, or biomass heat-only boilers, are cost-competitive against HP, which hampers the inclusion of HP in current DHC systems [2]. The use of fossil fuels-based techniques should be disincentivized to encourage low-carbon heating systems. HP integration can be encouraged by adjusting investments, operation subsidies, taxation [86], and electricity grid tariffs [87].

Another aspect of being considered is the acceptance rate of new heating technologies by the different stakeholders. For instance, the adoption of heat pumps at the industrial level has increased in recent years, but it still can be improved. In certain industries, the use of such technologies is considered a risk to the production and quality of products. 
However, heat pumps are being used in food, pulp, and paper industries but in a limited way [88]. The common objection is that new technologies may disturb the rhythm of production because of longer start-up times and different heat transfer mechanisms [7]. In the residential sector, there is a lack of willingness to adopt new technologies because of a lack of clarity on available information and behavioral barriers [7]. In order to boost the confidence of consumers and investors, demonstration projects should be promoted, and their benefits should be highlighted. To facilitate the investment in sector coupling and lowcarbon heating technologies such as heat pumps, it is important to develop a future policy with financial incentives for end-users as well as energy communities. In recent years, the concept of 'energy communities', in the wake of efforts owing to the Paris agreement [89], has received attention from researchers and policy makers [90]. EU overhauled its energy policies in 2019 and initiated a 'Clean energy for all Europeans package' in which energy communities have been added to the legislation [91]. These communities contribute to increasing the awareness about the usage of renewable energy projects and also help in enhancing the public acceptance rate. Such communities organize citizen-driven energy actions, which help in paving the way for the energy transition. Demos, pilot projects, sandboxes, and energy communities can be used to show that smart integration of sectors can be achieved using appropriate technologies [92], systems, and devices. Lessons learned through these pilot projects can then be communicated to scientific communities and industries, which can then suggest optimization and modification in techniques. An open exchange of data and results can accelerate the efforts in achieving sector coupling. In the context of energy communities, such technologies are required that are not too complex and have a higher acceptance and reliability rate. HP is one such technology that can play an important role here. Another significant thing is to increase self-consumption at the residential level. In a study made by Rinaldi et al. [93], it was concluded that HP provides increased local PV self-consumption. If a building has the possibility to install solar PV, wind turbine, $\mathrm{HP}$, or a micro $\mathrm{CHP}$, self-consumption can be increased by consuming a major portion of renewable energy being produced locally. In case of lack or excess energy production, it can be exchanged with the neighboring residential buildings, the main concept of energy communities, thus increasing the energy utility. This exchange of energy can be measured by smart meters [94]. Martorana et al. [95] analyzed the solar-assisted HP for supplying domestic hot water in energy communities of southern Italy. Three different solar technologies, namely PV, solar thermal, and photovoltaic thermal, were analyzed. It was concluded that PV-assisted HP is most suitable for the desired operation. Moreover, it was also recommended that a storage mechanism should also be present to serve the sudden change in demand since HP coupled with solar systems are not suitable for demand-response programs. In another study by Jambagi et al. [4], sector coupling of heat and electricity at the domestic level is analyzed. Two houses are considered, with one having micro CHP with electrical and thermal storage and the second house with a PV-assisted heat pump. Results show that having both electrical and thermal energy storage help CHP by maximizing its use. Moreover, the use of PV increased and reduced the cost of energy for households. The prospects of HP in sector integration of electricity and heat are quite bright, and a huge increment in the installation of HP is expected with the advent of projects aiming for electrification of the heating sector [96].

\section{Thermal Energy Storage for Power-Thermal End-Use Sector Coupling}

\subsection{Application of TES in DHC}

Thermal energy storage (TES) is the technology by means of which it is possible to store thermal energy, which can be used later in order to cover the mismatch between energy generation and its use. Implementing TES in an energy system results in better economics and more efficient use of energy while lowering $\mathrm{CO}_{2}$ emissions and increasing the system's reliability $[97,98]$. TES technologies can exploit sensible, latent, and thermochemical heat. A detailed classification of TES is given in Figure 8. 


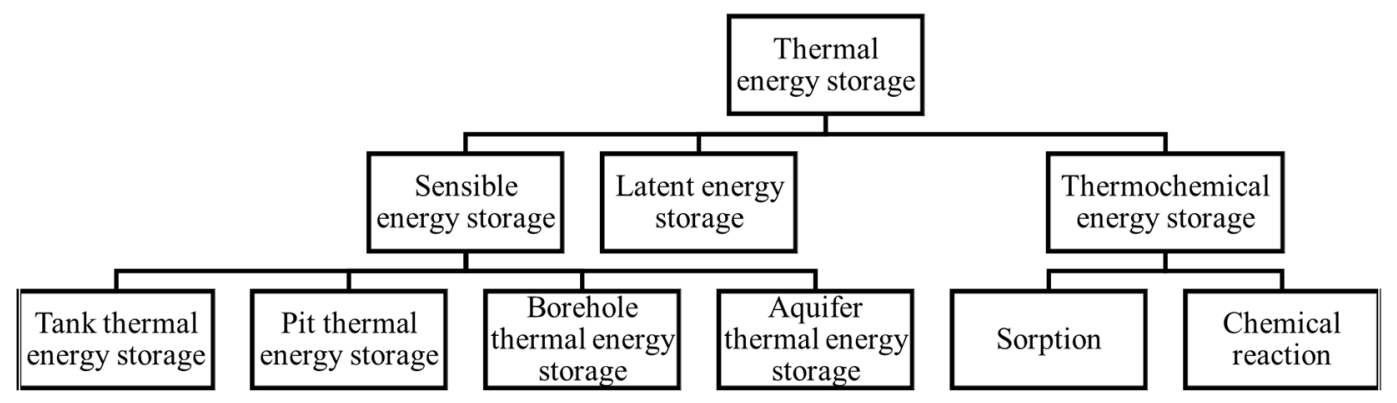

Figure 8. Classification of thermal energy storage.

Several reasons lie beyond the wide adoption of TES in DHC systems. The benefits, ranging from technical to economic to environmental, associated with TES in district heating are discussed in detail elsewhere [13]:

- Coping up with heat load variations due to demand side: DHC systems often face heat load variations that result in increased cost for heat/cold generation and an increase in greenhouse gas emissions because of use of fossil fuel use associated with the use of boilers as generators for peak load. In order to cope with heat load variations, thermal energy storage can smooth the peak heat loads;

- Coping up with variations in the generation side: which are mainly due to variable renewable energy sources, such as solar. As the penetration of renewables in the heating sector has increased in the past decade, the incorporation of thermal storage with the heating sector is crucial [99]. Moreover, different RESs have different time scales for variation (i.e., seasonal or daily) and therefore require different types of TES;

- Increasing flexibility of system: Integration of thermal energy storage with district heating increases the flexibility of the system. Flexibility in terms of district heating can be defined as the capacity to shift the energy supply in terms of time, temperature levels, and power levels [100];

- Less infrastructure for DHC: Connecting TES to DHC networks allows for the use of a shorter pipe size for the distribution network [101]. When TES is installed on the primary line, it helps in overcoming the issues related to mass flow circulation. Water can be circulated at lower flow rates, which allow for smaller pipe size, thus reducing the associated pumping costs;

- Energy savings and reduction in greenhouse gases: the application of TES systems in buildings, industry, and DHC systems not only provide an annual energy saving but also helps in reducing $\mathrm{CO}_{2}$ emissions [102].

\subsection{TES Technologies for DHC}

Before making an analysis on how TES can play an important role in sector integration, a description of its different types and latest status is presented below. Currently, TES is extensively used in district heating and cooling. Storage in thermal or hybrid grids can either be short or long term. Short-term storage (STS) includes the use of heat storage tanks, the thermal inertia of buildings, and the network pipeline of district heating and cooling (DHC). Long-term storage (LTS) uses boreholes, tanks, and pits. Short-term storage can be of the order of an hour up to a few days [103], while long-term storage is of the order of weeks up to a season (seasonal TES).

Within DHN, short-term storage can be centralized or decentralized. Having centralized storage tanks results in decreasing the total annual operating cost of a DH system as compared to no storage [103]. The operating cost increases because of heat load variations, and the presence of a storage mechanism helps in coping up with such variations, thus reducing the operating costs. Examples of such a type of storage are sensible storage close to generation plants (such as CHP or a centralized gas or biomass boiler); see Figure 9, which helps in covering peak demand time periods, enabling peak capacity of the plant to be reduced and to operate at full capacity for longer time periods [104,105]. The temper- 
ature ranges shown in Figures 9 and 10 are from the third generation [11]. These supply temperatures will drop considerably in upcoming generations.

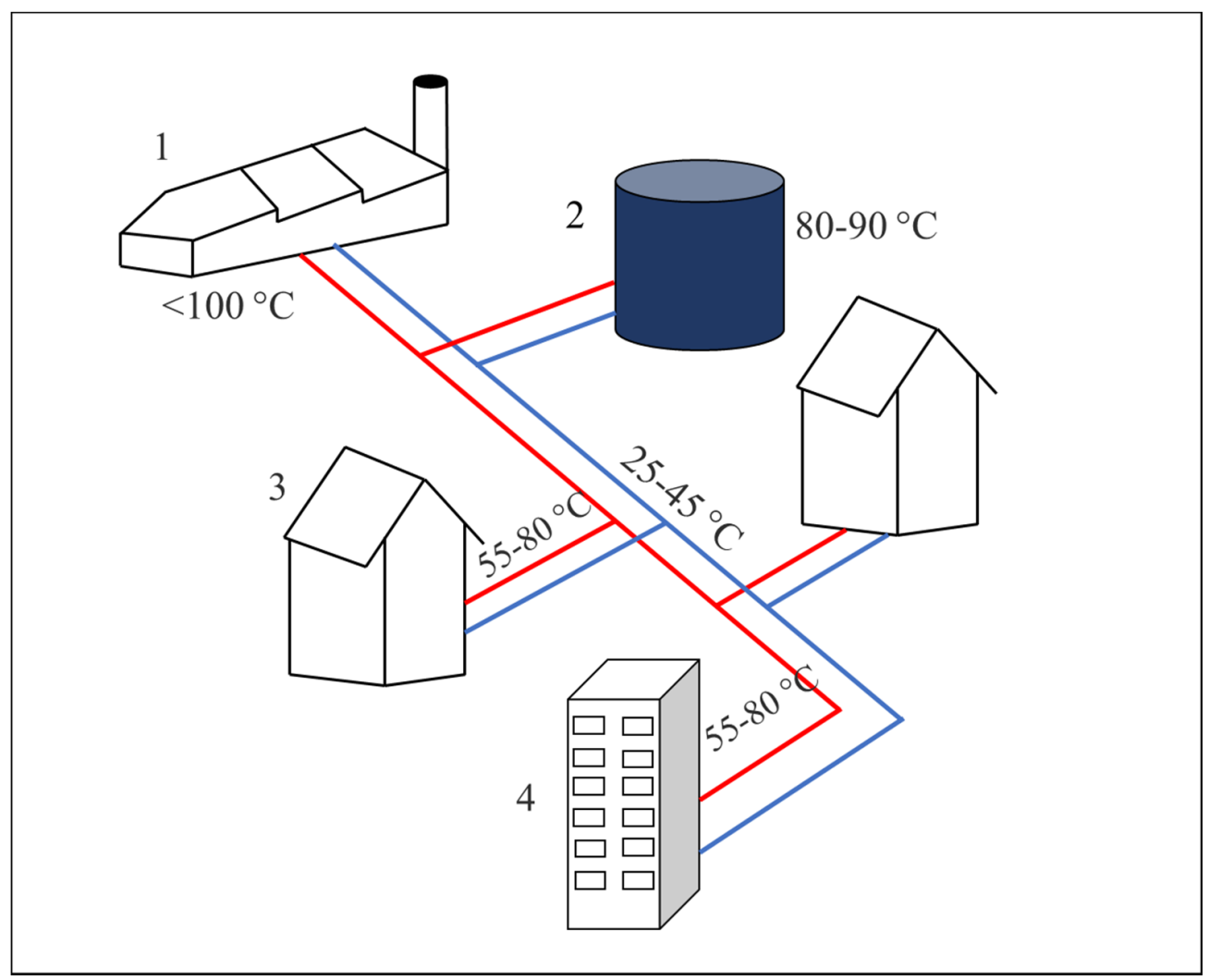

Figure 9. District heating and cooling with centralized storage (1-generation plant, 2-TES, 3,4-DH users).

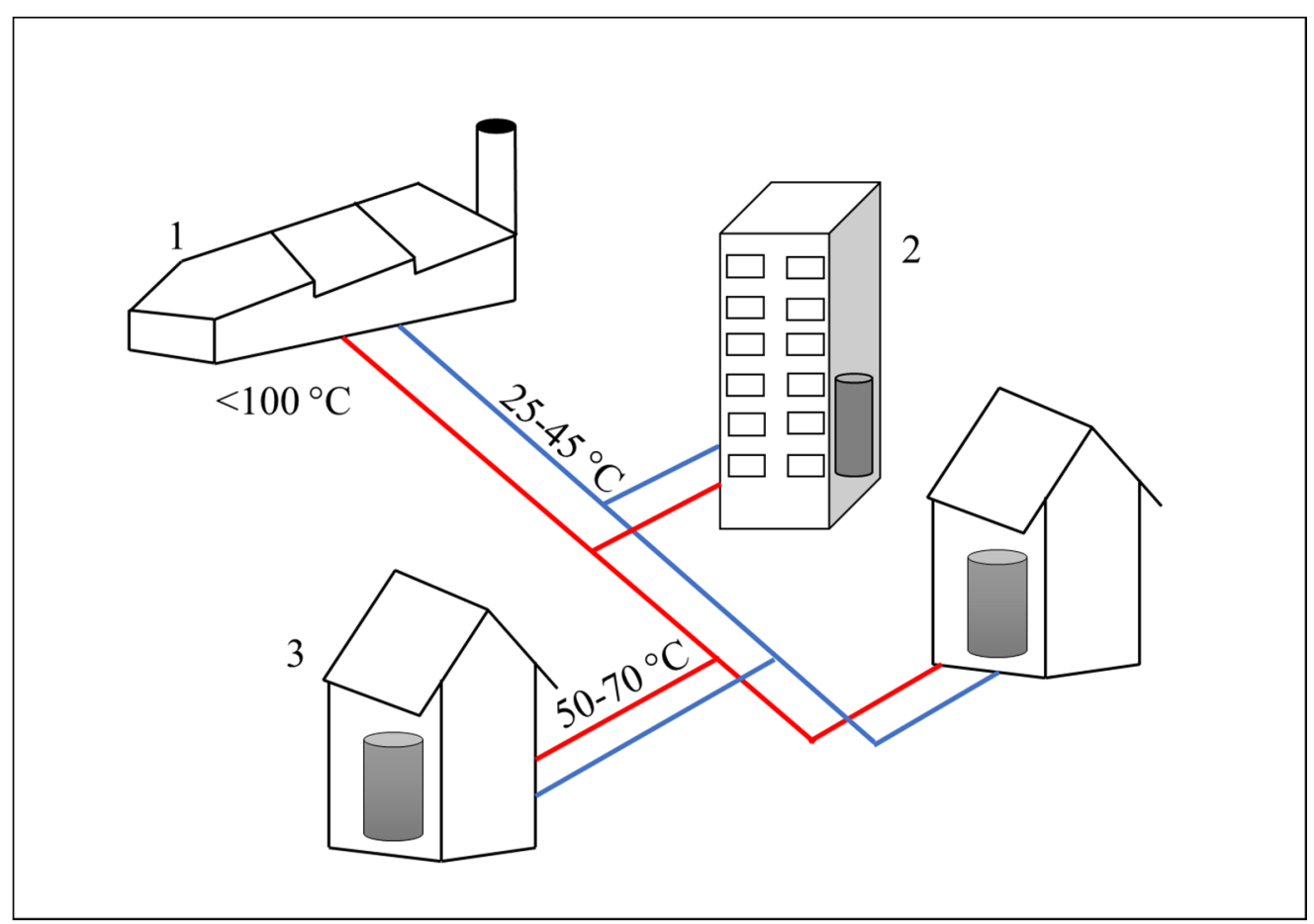

Figure 10. District heating and cooling with decentralized heating (1-generation plant, 2,3-DH users). 
The presence of TES in a DHN is beneficial in the way that it reduces the imbalance in the supply and demand gap. Dmytro et al. [103] made an analysis of thermal energy storage in district heating systems. Two storage types, i.e., centralized hot water tank (HWT) and building inertia thermal energy storage (BITES), were extensively analyzed in the context of heat load and supply. The study concluded that both storage technologies reduced the imbalance between heating load and supply. For the case considered in the study, hot water tanks proved to store double the amount of heat as compared to the thermal inertia of buildings. Moreover, it was observed that if the purpose is to store heat for more than $48 \mathrm{~h}$, HWT can come in handy. HWT has its full capacity available for charging and discharging, while BITES depends on many factors, including heat transfer between the building core and indoor environment. The results have further shown that both TES technologies are equally efficient in straightening out the daily net load variations. When compared at longer time intervals, HWT showed better performance in smoothening the load variations up to a few weeks because of its high potential to store heat and reduce losses. Relative daily net load variations decreased by $19 \%$ and $20 \%$, while weekly net load variations dropped by $10 \%$ and $17 \%$ for BITES and HWT, respectively, when compared to a scenario in which no thermal energy storage was present. It is then possible to use decentralized storage for DHC, which can be the exploitation of thermal inertia of buildings or realized by storing energy locally at the building level, usually through a sensible or latent heat storage system, as shown in Figure 10 [103].

Another solution for thermal storage inside DHC is the possibility of using the pipelines of the system. Even though this system can be effective in decreasing the daily peaks, it requires the increase in the temperature of the water supply, which increases distribution losses [106]. Furthermore, high return temperatures decrease the efficiency of the energy system [36]

The decentralized storage is usually part of a renewable-based system installed on the end-user section. In this case, the heat stored can be in the form of sensible or latent, or both contributions can be exploited, i.e., through a hybrid system [107] and used for domestic hot water and space heating purposes, as shown in Figure 11.

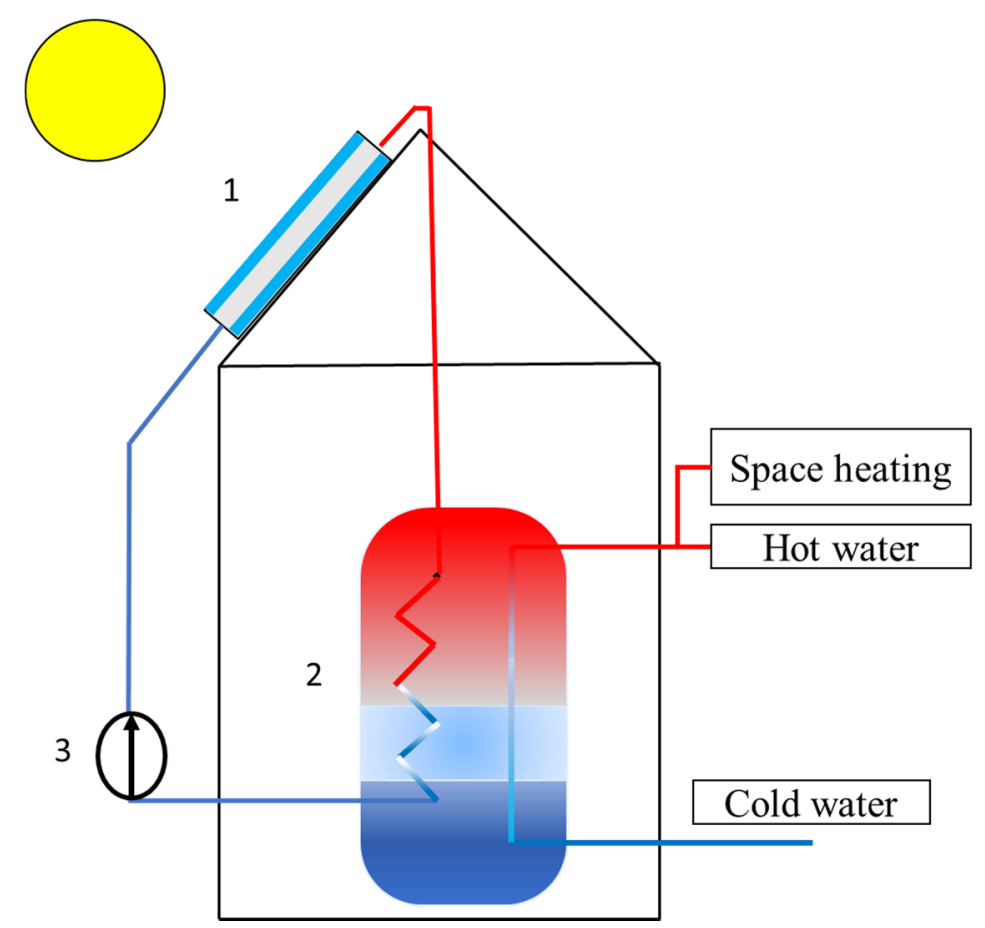

Figure 11. Meeting heating demands with solar thermal in residential building (1-solar thermal collector, 2-TES tank, 3-pump). 
For cold storage purposes, water/ice is used because of its low cost and high latent enthalpy. Chan et al. reported a DC system combined with ice storage [108] and discussed the economics of the use of such a solution. Results indicate that, although considerable savings can be achieved during operation, payback time is estimated to be 22 years due to the higher installation cost and electricity tariffs.

Alongside sensible storage, LTES is also suitable for applications in district cooling systems. He et al. [109] investigated a PCM paraffin wax for cold storage in a district cooling (DC) system with the aim of peak shaving. It was concluded that using PCM storage combined with an absorption chiller not only helps in peak shaving but also reduces the storage size. According to the results, the storage size of PCM was $61.5 \mathrm{~m}^{3}$, while a stratified chilled tank would require a volume of $690 \mathrm{~m}^{3}$. In DC systems, the temperature difference between supply and return temperatures is much lower as compared to $\mathrm{DH}$ systems, and therefore, a larger storage volume is needed. Having a latent system results in a reduction in specific volume as compared to a sensible system [36].

In addition to short-term storage, DHC often makes use of seasonal thermal energy storage, which can store heat for longer periods of time, ranging from days to weeks and even months. For applications concerning long storage times, thermochemical and latent seasonal storage technologies are still in the laboratory-scale testing phase, while sensible seasonal storage technologies have been in operation for a long time [110,111]. Some of the widely used seasonal storage techniques are briefly described below. These technologies have been termed promising for sector integration of power and heat [112] Moreover, such storage techniques also allow a greater share of renewables to be incorporated and can also make use of HP in conjunction.

Aquifer thermal energy storage (ATES) is a method for storing heat underground for long periods of time. Two wells are usually employed, namely cold and warm wells. When charging needs to be performed, water from the cold well is extracted and passed through a heat exchanger. After water absorbs heat, it is injected into the warm well. For cooling purposes, a reverse process is performed. The temperature of the ATES system is limited to $50^{\circ} \mathrm{C}$ because temperatures above this limit cause a change in the chemical properties of soil [113]. Figure 12 shows the use of this technology in the summer and winter seasons within DHC. Most often, the storage temperature is not sufficient enough for the whole heating season. So, a supporting equipment, e.g., heat pump, is required to elevate the temperature to the user level [114]. In the case of low-temperature energy storage, heat pumps can be used to raise the temperature needed for domestic hot water and space heating.

Pit thermal energy storage (PTES), another technology adopted in DHC, is shown in Figure 13. It resembles a large pool covered with an insulating roof. Water is pumped into or out of the storage unit to add or extract energy. This technology can be helpful in the successful implementation of energy systems' transformation to renewable-based ones. If higher temperatures are needed, a heat pump may be used to elevate the temperatures. Sorknæs [114] developed a simulation model for integration of PTES with HP and validated it by testing it on Dronninglund DH for the year 2015. Results found were in close proximity to actual ones. One of the biggest examples of PTES storage system is Marstal Fjernvarme on the island of Ærø, Denmark [115], which involves the heat pumps [116].

Borehole thermal energy storage (BTES), shown in Figure 14, is another seasonal storage technology being applied in DHC. This storage system can be used in almost all geological conditions. The higher temperature of storage results in higher COP values of ground source heat pumps, and therefore, less electricity is required [117]. Nam et al. [118] concluded that employing ground source HP coupled with solar thermal energy help in maintaining better ground temperature balance and perform at higher COP values over their lifespan.

TCMS (Thermochemical storage) is also used to store heat seasonally. The working principle of a TCMS can be found elsewhere [119]. One of the main strengths of using TCMS lies in its high energy density, which is about $400 \mathrm{MJ} / \mathrm{m}^{3}$ [120], while the energy 
density of water is around $200 \mathrm{MJ} / \mathrm{m}^{3}$ when a temperature difference of $50^{\circ} \mathrm{C}$ is considered. Another benefit associated with TCMS is its low thermal losses over time. Indeed, the storage process is related to the thermochemical reaction potential occurring between two components. During charging, the energy is spent to separate the two components. Accordingly, the stored energy is almost unaffected by heat losses since it is guaranteed as long as the two components are kept separate. Once the energy is needed, the recombination of these components releases the stored energy [119]. The concept of TCM seasonal storage installed within a thermal network is shown in Figure 15.

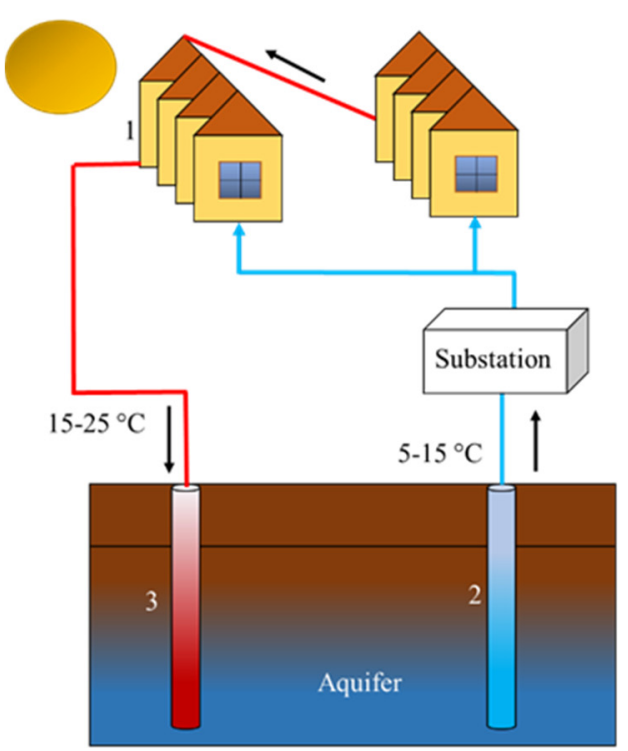

(a)

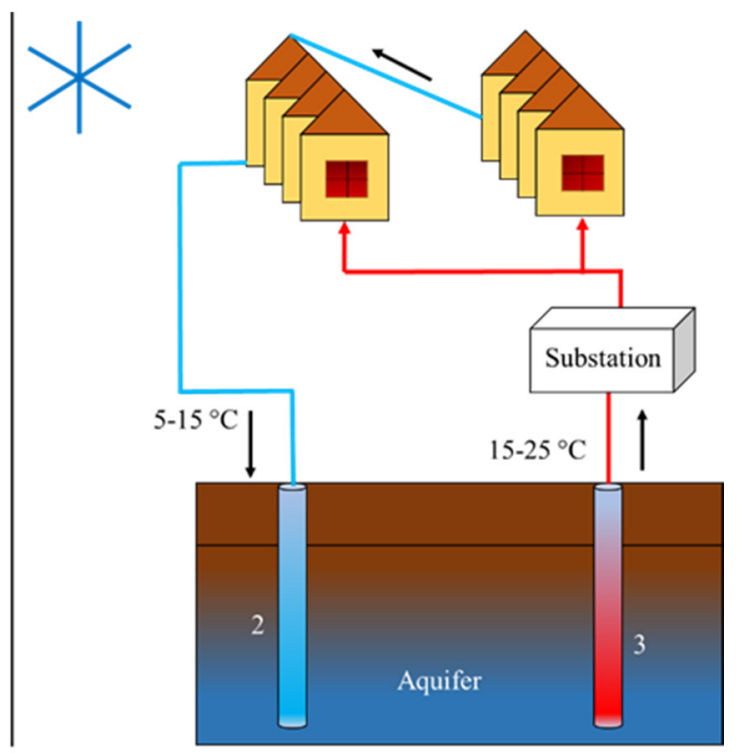

(b)

Figure 12. Aquifer thermal energy storage in summer (a) and winter (b). 1-DH users, 2-cold well, 3-warm well.
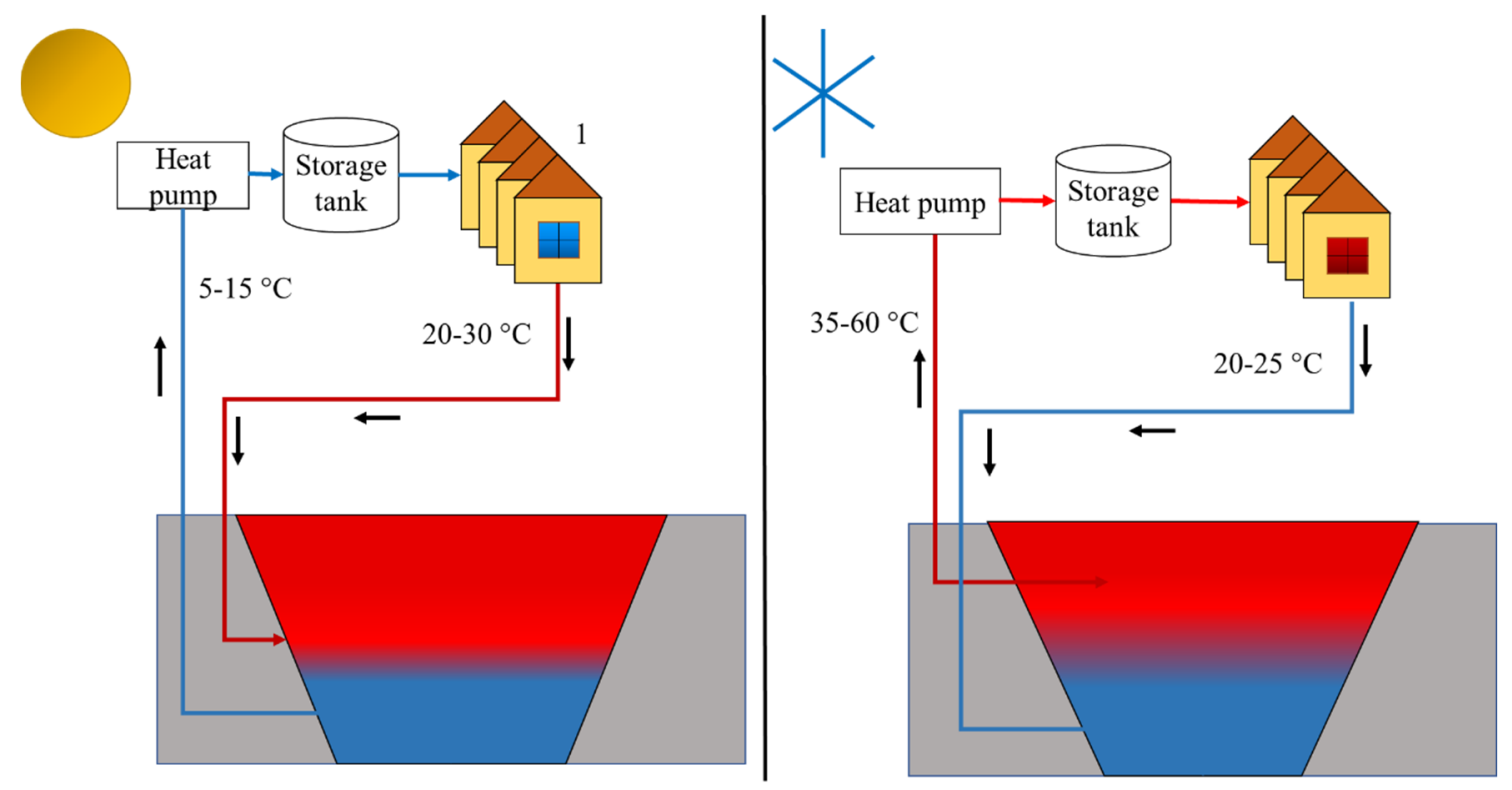

Figure 13. Seasonal pit storage in summer (left) and winter (right), $1-\mathrm{DH}$ users.

Hui et al. [121] investigated seven different absorption working pairs to find a feasible combination with convenient properties for seasonal storage of solar energy for a house heating system. These couples were $\mathrm{CaCl}_{2} / \mathrm{H}_{2} \mathrm{O}$, glycerine $/ \mathrm{H}_{2} \mathrm{O}, \mathrm{KOH} / \mathrm{H}_{2} \mathrm{O}, \mathrm{LiBr} / \mathrm{H}_{2} \mathrm{O}$, $\mathrm{LiCl} / \mathrm{H}_{2} \mathrm{O}, \mathrm{NaOH} / \mathrm{H}_{2} \mathrm{O}$, and $\mathrm{H}_{2} \mathrm{O} / \mathrm{NH}_{3}$. The analysis showed that none of the mentioned 
absorption couples turned out to be suitable for $\mathrm{DH}$ applications because of not reaching the required temperature threshold.

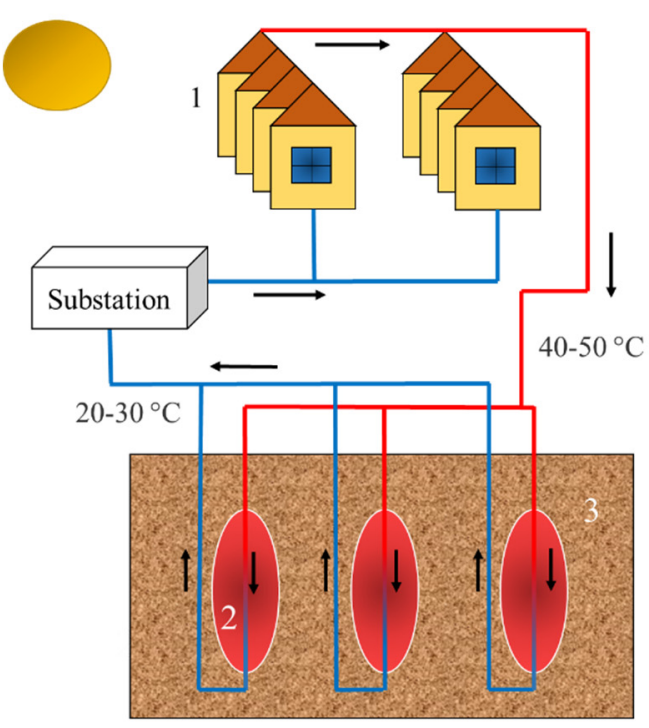

(a)

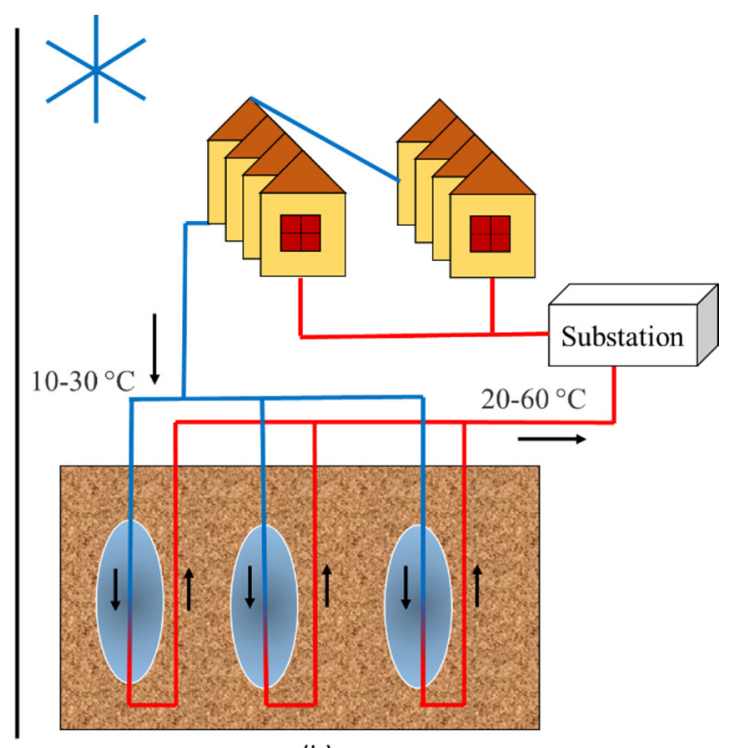

(b)

Figure 14. Borehole thermal storage in summer (a) and winter (b). 1-DH users, 2-borehole, 3-soil underground.
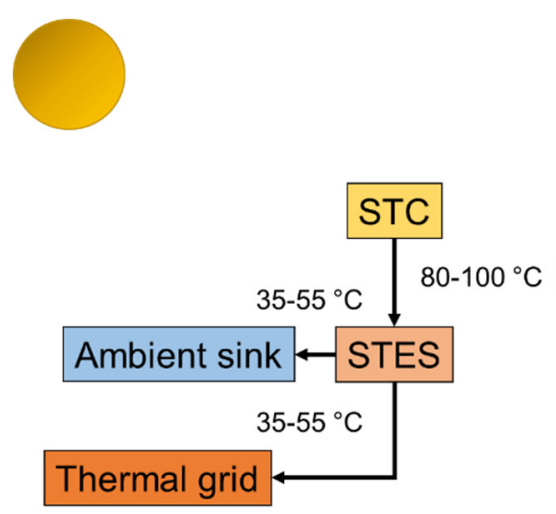

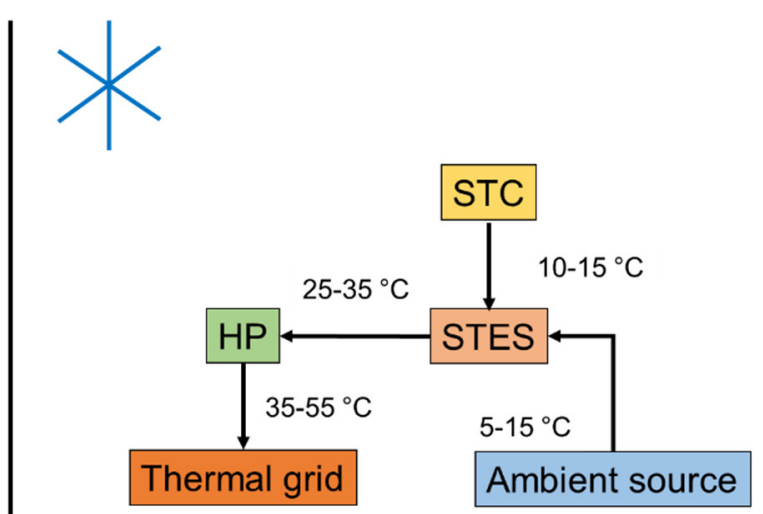

b

Figure 15. TCM seasonal storage charging phase (a) and discharging phase (b).

In Munich, a large sorption zeolite prototype for two buildings was investigated with the intention of peak shaving in summers and winters [122]. The hot source was provided through a DH network, while the cold source was made available from the returning line of the DH system. Optimal desorption temperature for best performance was investigated. The payback period of this system was found to be in the range of 7-8 years. Results showed that $86 \%$ of theoretical maximum efficiency and $81 \%$ of theoretical maximum thermal energy density were reached. Moreover, the prototype helped in straightening out the load profiles of both buildings. 


\subsection{TES as Enabling Technology for Sector Coupling}

The main benefits for the application of TES in DHC were discussed in Section 5.1, but its potentialities are even higher when considering the sector coupling with the electric network [110].

Both sensible and latent TES technologies have been termed as promising technologies for sector integration in a report published by IRENA in 2020 [110]. According to the report, sensible technology is suitable for sector coupling because of its high maturity and commercial availability, while latent TES has a very low physical footprint and high energy density. Among seasonal storage technologies for sector integration, all the abovementioned technologies, namely ATES, PTES, and BTES, have been termed promising, and the development of these technologies has been considered encouraging [114]. Examples at the commercial level are quite low as these technologies have still not reached commercial readiness. Steinmann et al. [123] analyzed the prospects of PTES technology for sector coupling of heat and electricity. It was concluded that PTES has great potential as an enabling technology for sector coupling. IRENA terms TCMS as an interesting and promising technology from a sector coupling point of view, but it is still in the applied research and prototype phase [110]. The examples in literature for TCMS as a service for sector coupling are also limited. Cammarata et al. [124] developed a storage device based on thermochemical materials to store excess generated power. The aim was to develop a storage system for household applications for a temperature range of $50-100{ }^{\circ} \mathrm{C}$. The material used was strontium bromide $\left(\mathrm{SrBr}_{2} \cdot 6 \mathrm{H}_{2} \mathrm{O}\right)$ and graphite as an additive material. It was concluded that the concerned material is a suitable fit for storage applications, which also makes it feasible for sector coupling. Ferruci et al. [125] developed compressor-driven thermochemical storage for cooling applications in households. The mechanical-driven compressor is powered by grid and PV electricity. The thermochemical material being used is pair of $\mathrm{BaCl}_{2} / \mathrm{NH}_{3}$. In case of excess electricity and no cooling load, energy will be provided to the compressor to store energy. It was concluded that the proposed system can provide cooling and energy storage in the context of smart grids. Fito et al. [126] studied an ammonia-based refrigeration system consisting of compression refrigeration with thermochemical storage. The configuration of the system consisted of a heat pump, a grid-connected solar PV, and a thermochemical storage reactor. Electricity requirements for meeting the cooling demand are covered by solar PV and the grid. In case of excess RES power generation, it is used to store energy in the form of heat by the desorption phase of the reactor.

TES can play an important role when the integration of electricity or gas grids with DHC is foreseen. Typical energy vector conversion systems are power-to-heat, heat pumps, heat-only boilers, power plants, and cogeneration plants. Energy can be converted to other forms and stored while guaranteeing economic and environmental feasibility. Indeed, as already mentioned, TES allows for better use of RES. Since the majority of renewables produce electricity, TES increases the flexibility of the system because it helps in reducing the variability and uncertainty of RES by storing energy in the form of heat at the time of production and releasing later for use when required; this allows covering the gap between generation and demand $[127,128]$. Heat pumps can be used for energy storage purposes in this case. When electricity is in excess, it is converted to thermal energy using $\mathrm{HP}$ and is stored. Moreover, TES allows for better use of CHP plants in the framework of optimized management of the whole energy system. CHP is often controlled according to the electricity demand needed at a certain time. However, the heat produced at the required part load does not always meet the thermal demand. The presence of TES will help in keeping the desired part load without wasting the produced heat. It was demonstrated that with such a strategy, it is possible to integrate renewable electricity around $20-25 \%$ of total demand without hindering the overall efficiency of the CHP system [39]. CHP plants use then results in maximized profits $[129,130]$. The presence of TES makes it possible also to shift the electricity production to hours when the unit price is higher [131]. Ramm et al. [132] explored the integration of heat pumps and TES with CHP and how this 
integration allows stabilizing the electric and thermal grids. The study concluded that it is possible to couple thermal and electricity grids by using heat pumps, TES, and CHP through a controlled strategy, and stability can be provided to a low and medium voltage grid. The application of a suitable management technique to control the operation time of CHP and HP to exploit the opportunities to stabilize the grid was suggested.

Another effect of using TES coupled to power-to-heat systems such as heat pumps is that TES improves the operation of the heat generation system by reducing the temperature fluctuations, thus increasing its efficiency. It is then discussed in some studies that in this way, the burden on the electric grid is reduced [103]. A similar effect is achieved by using TES as a way to support the time of rapid demand; using the stored heat allows reducing the need for oversized boilers or chillers, which consume a high amount of electricity, especially during start-up.

The possibility of using TES for sector coupling opens up also another path, i.e., the replacement of part of the electricity storage with thermal storage. Regarding electricity storage, two techniques have been applied at a large scale, i.e., pumped hydro energy storage (PHES) and compressed air energy storage (CAES) [5]. Compared to them, TES possesses many features, which makes it a valid alternative:

- TES systems are less expensive, with costs at around $0.5-3 € / \mathrm{kW}$, while costs of CAES and PHES lie around $170 € / \mathrm{kW}$ [133]. Another study carried out by Scapino et al. [134] estimated the cost of TES in the range of 10-50 USD \$/kWh, while CAES had its cost in the range of $2-100 \mathrm{USD} \$ / \mathrm{kWh}$;

- $\quad$ CAES and PHES technologies lead to significant losses, and roundtrip efficiencies are $65 \%$ and $85 \%$, respectively [5]. TES, on the other hand, minimizes roundtrip conversion losses;

- $\quad$ TES leads to higher efficiencies when RES are integrated as compared to electric storage [5];

- The lifetime and capacity of TES systems are also higher than the other two technologies mentioned [135].

It is worth noticing that the economics of this solution is also profitable. The installation of TES systems is not expensive, especially for the sensible technology, whose cost ranges between 0.1 and $10 € / \mathrm{kW}$ [136]. Currently, sensible TES is the most attractive technology to store energy in an electrical network for a longer period in an economical way [137]. Rech and Lazzaretto [138] discussed the optimization of an energy system operation fed by RES and connected to a grid. It concluded that TES is the best system to optimize the working of energy systems while electrical storage may appear unfavorable. There is another technology for the energy storage process in large electrical applications known as 'Pumped thermal energy storage', and it involves both HP and TES [139]. It has been termed as a key technology for sector integration while also providing the possibility to incorporate increased RES penetration [123]. In pumped thermal energy storage, heat from a low-temperature source is converted to high-temperature heat through heat pumps and is stored in a thermal storage unit. Later, heat is discharged, and mechanical work is produced through a thermal cycle. Steinmann et al. [123] studied the possibility of using pumped thermal energy storage as a sector coupling technology with butene as a working fluid. The thermal storage unit is charged with steam at 350 to $400{ }^{\circ} \mathrm{C}$ and at a pressure of 100 bar. Roundtrip efficiency of $70 \%$ has been achieved. Wang et al. [140] proposed a pumped heat electricity storage based on the Brayton cycle. The behavior of storage units was observed under four different operation modes, namely series, parallel, in sequence, and a novel mode named 'temperature complementation'. It was claimed that the proposed novel mode requires low TES unit volume and cost. Moreover, it was also mentioned that pumped heat electricity storage has efficiencies and energy densities comparable to CAES. The storage with series-connected reservoirs resulted in a roundtrip efficiency of $64.9 \%$. Under novel mode, the delivery stability of power improved by $13.2 \%$. Moreover, it was mentioned that with the proposed novel mode, the size of the TES reservoir can be reduced by 1.8 times while having roundtrip efficiencies of $63-65 \%$. The novel mode 
has been proposed to increase the delivery stability since it was observed that the stability of power delivery was low in other operating modes. It is accomplished by controlling the operating time and flow rate of each reservoir. It is important to mention here that the quality of energy drops in TES because of losses attributed to it. The process of converting heat to electrical energy is quite complicated. There are different methods to do so, and each method has its own requirements and limitations [141].

TES can also be incorporated at the local level in order to support the integration of varying RES. Arteconi et al. [59] conducted a study to analyze the installation of small TES systems and heat pumps in buildings for demand-side management and power balancing. The aim was to flatten the electricity load curve by switching off the heat pumps during peak hours and to assess the thermal comfort of occupants inside the house. The temperature control of the building under consideration was strongly affected by the thermal mass of the system when heat pumps were turned off. For example, thermal comfort was maintained through underfloor heating even when heat pumps were turned off. For heating systems with low thermal mass, such as radiators, TES becomes necessary to be installed to improve temperature control. Results show that electricity bills can be reduced by using the 'time-of-use' tariff and by using incentives on renewable heat generation, if available.

Finally, TES has the ability to overcome the limitations of certain technologies associated with DHC and to boost their advantages. TES installation allows CHP to operate at full capacity when electricity prices are high while keeping the stored heat intact. For DH purposes, CHP-DH is the most common and widespread technology. The use of TES has proven to increase in flexibility of CHP operation [5]. Moreover, the size of the installed capacity of power generation units can be reduced if TES is integrated with a CHP, and profits have been observed to be increased. An increment in the capacity of CHP has been proved not to affect the flexibility, while the buffer size has an almost linear effect on it [142]. A TES system tailored according to the needs of a CHP helps the plant to run at optimal conditions. A reduction of almost three times is observed in the greenhouse gas emissions when TES is integrated with CHP-DH combination in a study carried out by Haeseldonckx et al. [143]. Moreover, Al-Qattan et al. [144] discussed the integration of TES in DH with fuel cells and concluded that this combination resulted in an efficiency increase of around $346 \%$ while decreasing the carbon emissions by $54 \%$ [144]. A study by Verda and Colella [145] about thermal energy storage in district heating networks concluded that total annual costs can be reduced by $5 \%$.

Despite such benefits, different barriers to the implementation of TES technologies can be identified. There is a lack of technology readiness related to some TES technologies. TES is a 'relatively new' technology that is competing against technologies with high TRL (technology readiness level), e.g., low-cost fossil-generated heating [110]. Moreover, there is a lack of knowledge and awareness confidence in how TES can prove to be beneficial for the power, heating, and industrial sector. This lack of confidence has been recently demonstrated when research and development's focus was disproportionately shifted to electrical battery storage despite the proven fact that TES can incorporate high levels of RES. TES projects are generally long-term and large-scale projects. Currently, there is uncertainty on how a future energy system would look like and the way it will develop through the transition phases, which leads to reluctance to invest in long-term projects. Another technical issue to be tackled through dedicated R \& D is the design of TES for DHC, which requires the knowledge of network dynamics and the development of ad-hoc tools for planning and selection of the best technology. This is particularly true for seasonal TES; that, however, demands more attention as it is one of the best ways to make full use of heat sources such as solar, geothermal, and waste heat. More case studies are required on selection-procedure of type of seasonal storage to know about different decision criteria that should be taken into account to check the feasibility as each type of seasonal storage has its own requirements and limitations. For example, ATES needs particular geological conditions with water-saturated sand layers having high permeability without natural 
groundwater flow. If these conditions are not met, then clogging effects start to appear, which are difficult to manage. If the geological conditions are not checked carefully before the initiation of the project, irreparable damages take place, and unexpected disadvantages appear. Moreover, the soil formation and composition also need to be checked before drilling holes and bores. High thermal losses are also a serious problem associated with seasonal storage. Moreover, proper insulation is needed to reduce losses and leakage from storage. From the technical point of view, another issue to be considered is the definition of robust monitoring and control models, which can exploit the maximum benefit from all energy resources associated with a system. A vision on the barriers and development path for the various TES technologies toward a higher TRL for various applications, including DHC, is given in the work of [146].

Apart from technical issues, future smart energy systems call for a unified policy as the aim is to develop MCES that carry different energy vectors. Currently, there is siloed thinking for each energy vector, which often leads to conflicting policies and inefficient future planning. The heating sector is yet lacking a solid policy for decarbonization as compared to the power sector [110].

Policy makers and actors from the energy sector can tackle the above-mentioned issues by technology push, market pull, and enabling mechanisms to encourage the wide deployment of TES projects [110]. The focus should be increased on building an integrated energy policy for the heating and cooling sector with the incorporation of TES to achieve benefits. An all-system approach is required to analyze available technologies across all energy vectors to devise the most cost-effective way for the energy transition. Demonstrations related to the research and development of TES should be regularly funded in order to increase market awareness, build consumers' confidence and progress the TRL [110]. In short, more investment is needed in the R\&D of TES technology. Policy makers can consider removing or decreasing subsidies on the use of fossil fuels, which would certainly help in increasing the competitiveness of low-carbon heating technologies. A comprehensive market mechanism is required, which should address time-of-use tariffs to help reduce the consumers' bills and furthermore should also provide revenue incentives for owners and operators of TES systems [110].

Up till now, it has been discussed how HP and TES can play a significant role in sector coupling. In the coming paragraphs, the impacts on the power sector as a result of sector coupling will be discussed. Sector coupling helps to improve the flexibility and efficiency of energy systems while also adding to the reliability and adequacy. Moreover, sector coupling can also provide voltage control, congestion management, and balancing supplydemand frequency regulation as additional support. It is also the answer to growing flexibility needs in EU power systems because of increasing RES share. There have been various examples from EU countries when RES provided $100 \%$ of the power demand, and the high availability of RES is leading to scenarios related to negative prices in the market [6]. Therefore, several member states with a high share of RES in the energy mix have the challenge of making their power systems flexible in order to match supply and demand at any moment. This challenge can be overcome by the combined use of HP and TES. Although several solutions have been applied, the repeated occurrence of negative prices in the spot market implies that more efforts and options are needed. According to a position paper from DNV [147], the flexibility offered to the electricity sector by sector coupling comes in different forms. Besides traditional fixed demand, two new parameters come into play that are known as responsive and opportunity demand. According to the authors, responsive demand helps in absorbing large fluctuations for a short interval of time. Opportunity demand, on the other hand, gives an additional dimension to the price-forming mechanism as this demand can become price-setting based on the cost of alternative options. A price-setting strategy is a mechanism to set the prices of a product seeing its demand in the market. It is mentioned that heat pumps and electric vehicles have the potential to absorb large amounts of renewable electricity, thus shifting demand toward high renewable production. Moreover, it is also mentioned that with an increase 
in renewable electricity, the need for large energy storage mechanisms will also increase. Thus, TES can play an important role here in aiding sector coupling [148].

Sector coupling provides support to the connected sectors in order to exploit synergies while leading to a more energy and cost-efficient power system [149]. It also helps to better use the abundantly available RES as mentioned above. Power-to-heat technologies combined with thermal energy storage help to convert electricity to heat and store it during the abundant and cheap availability of electricity [147]. Stored heat can be used to meet either thermal demand or to produce electricity later. In the same way, electricity can be converted to liquid fuel (methanol, for example) or to hydrogen through electrolyzers [6]. The electrification of the heating and transport sector is very likely in the near future. An increase in electricity demand in these sectors will cause an increase in electricity prices, which may help in positive business cases for RES power generation. After the above discussion, it is quite clear that HP and TES technologies can play a significant role in sector coupling. Moreover, sector integration is beneficial to both the power and heat sectors and is the need of the hour.

\section{Conclusions}

In this paper, a comprehensive review of the role of heat pumps and thermal energy storage technologies in the context of sector coupling is made. The main emphasis is on sector integration of electricity and heat. The concept and need of sector coupling are explained in the beginning. Before making an analysis on how HP and TES can be helpful in enabling sector coupling, the current status of both technologies is reviewed. Both these technologies are being used in district heating and cooling and will assume a major role in upcoming generations of DHC. HP technology is concluded to have a huge impact on the decarbonization of fifth generation DHC networks.

The role of HP in smart electric grids, in the context of sector coupling, was discussed to understand how this technology would help in supplying ancillary services to the grid and in enabling the integration of renewable energy sources (RES). Moreover, HP technology has the potential to be used in interconnected energy systems and would greatly help in bringing efficient and renewable practices in the future. Several studies found in the literature concluded that HP, while providing supplementary services to the grid, could help in voltage control and congestion management. Furthermore, HP could also help in balancing generation demand and frequency regulation. Solar and wind power could also be integrated with variable speed HP to increase the on-site consumption of energy.

Different TES technologies, namely sensible, latent and thermochemical, were discussed in terms of their applications in DHC and multi-carrier energy systems. Literature shows that TES can contribute to smoothening net load variations and can cause a reduction in $\mathrm{CO}_{2}$ gases. Seasonal storage techniques are termed equally important and significant, by an IRENA report, for sector integration of power and heat. From the findings of this review, it could be considered that the use of TES in smart grids will increase considerably in the future as it helps in increased renewable penetration. Moreover, the use of TES will help to reach the core objective of the Paris agreement, which is to promote clean energy initiatives and to reduce greenhouse gas emissions. A comparison of TES with compressed air energy storage and pumped hydro energy storage is performed in order to provide a clear view of the financials involved in employing these technologies. TES supersedes both the above-mentioned technologies in economic competitiveness. Moreover, the latest studies on pumped thermal energy storage, which use both HP and TES technologies, are also mentioned. Pumped thermal energy storage is termed a promising technology for large-scale electrical storage.

Apart from technical barriers, the economic, social, and political barriers are also discussed. Both heat pumps and TES have not been in the focus of national incentives, and economic support to their implementation is missing. Moreover, suitable business models need to be defined, which can increase the market penetration of the investigated technologies. A common plan and assessment to incorporate HP and TES for sector 
integration are still missing at the policy level, and strong efforts are required to materialize the vision of an integrated energy system. The use of both technologies will help in easing the transition toward energy-efficient ways to reduce carbon footprint. Moreover, both these technologies will be helpful in the decentralization of energy generation and storage. Finally, social aspects are discussed, and it is highlighted that the lack of clarity and low acceptance rate of the technologies is strongly hindering their installation and widespread adoption. Suggestions are provided in order to speed up the extensive adoption of investigated technologies.

Author Contributions: Conceptualization, O.A.R. and V.P.; methodology, O.A.R.; formal analysis, O.A.R., V.P. and A.F.; investigation, O.A.R.; resources, L.F.C.; writing-original draft preparation, O.A.R.; writing-review and editing, V.P., A.F. and L.F.C.; visualization, O.A.R.; supervision, V.P. and A.F.; funding acquisition, L.F.C. All authors have read and agreed to the published version of the manuscript.

Funding: This work was partially funded by the Ministerio de Ciencia, Innovación y Universidades de España (RTI2018-093849-B-C31-MCIU/AEI/FEDER, UE) and by the Ministerio de Ciencia, Innovación y Universidades-Agencia Estatal de Investigación (AEI) (RED2018-102431-T).

Institutional Review Board Statement: Not applicable.

Informed Consent Statement: Not applicable.

Data Availability Statement: Not applicable.

Acknowledgments: This work was partially funded by the Ministerio de Ciencia, Innovación y Universidades de España (RTI2018-093849-B-C31-MCIU/AEI/FEDER, UE) and by the Ministerio de Ciencia, Innovación y Universidades-Agencia Estatal de Investigación (AEI) (RED2018-102431-T). The authors at the University of Lleida would like to thank the Catalan Government for the quality accreditation given to her research group GREiA (2017 SGR 1537). GREiA is a certified agent TECNIO in the category of technology developers from the Government of Catalonia. This work is partially supported by ICREA under the ICREA Academia program.

Conflicts of Interest: The authors declare no conflict of interest.

\section{Nomenclature}

ATES Aquifer thermal energy storage

BTES Borehole thermal energy storage

BITES Building inertia thermal energy storage

COP Coefficient of performance

CHP Combined heat and power

CAES Compressed air energy storage

$\mathrm{DH} \quad$ District heating

DHC District heating and cooling

DHN District heating network

DHW Domestic hot water

EU European union

GHG Greenhouse gases

HP Heat pumps

HWT Hot water tank

IEA International Energy Agency

LTES Latent thermal energy storage

LTS Long-term storage

MCES Multi-carrier energy system

PCM Phase change materials

PV Photovoltaic

PTES Pit thermal energy storage

PHES Pumped hydro energy storage

RES Renewable energy resources

STS Short-term storage 
TES Thermal energy storage

TCMS Thermochemical storage

TRL Technology readiness level

\section{References}

1. Electricity Mix-Our World in Data. Available online: https:/ / ourworldindata.org/electricity-mix (accessed on 15 June 2021).

2. Kirkerud, J.G.; Bolkesjø, T.F.; Trømborg, E. Power-to-heat as a flexibility measure for integration of renewable energy. Energy 2017, 128, 776-784. [CrossRef]

3. International Energy Agency. Statistics Report Key World Energy Statistics 2020; Springer: Berlin/Heidelberg, Germany, 2020.

4. Jambagi, A.; Kramer, M.; Cheng, V. Electricity and Heat Sector Coupling for Domestic Energy Systems Benefits of Integrated Energy System Modelling. In Proceedings of the 2015 International Conference on Smart Cities and Green ICT Systems (SMARTGREENS), Lisbon, Portugal, 20-22 May 2015.

5. Mathiesen, B.V.; Lund, H.; Connolly, D.; Wenzel, H.; Ostergaard, P.A.; Möller, B.; Nielsen, S.; Ridjan, I.; KarnOe, P.; Sperling, K.; et al. Smart Energy Systems for coherent 100\% renewable energy and transport solutions. Appl. Energy 2015, 145, 139-154. [CrossRef]

6. Van Nuffel, L.; Gorenstein Dedecca, J.; Smit, T.; Rademaekers, K. Sector Coupling: How Can it be Enhanced in the EU to Foster Grid Stability and Decarbonise; European Parliament: Brussels, Belgium, 2018.

7. Münster, M.; Sneum, D.M.; Bramstoft, R.; Bühler, F. Sector Coupling: Concepts, State-of-the-art and Perspectives Low Carbon London View Project Design and Optimization of Flexible Multi-Generation Systems View Project. Available online: https: / / www.researchgate.net/publication/339365854 (accessed on 12 July 2021).

8. Arabzadeh, V.; Mikkola, J.; Jasiūnas, J.; Lund, P.D. Deep decarbonization of urban energy systems through renewable energy and sector-coupling flexibility strategies. J. Environ. Manage. 2020, 260, 110090. [CrossRef] [PubMed]

9. European Commission. The European Green Deal; European Commission: Brussels, Belgium, 2019.

10. Eveloy, V.; Ayou, D.S. Sustainable district cooling systems: Status, challenges, and future opportunities, with emphasis on cooling-dominated regions. Energies 2019, 12, 235. [CrossRef]

11. Paiho, S.; Saastamoinen, H.; Hakkarainen, E.; Similä, L.; Pasonen, R.; Ikäheimo, J.; Rämä, M.; Tuovinen, M.; Horsmanheimo, S. Increasing flexibility of Finnish energy systems-A review of potential technologies and means. Sustain. Cities Soc. 2018, 43, 509-523. [CrossRef]

12. Perez-Mora, N.; Bava, F.; Andersen, M.; Bales, C.; Lennermo, G.; Nielsen, C.; Furbo, S.; Martínez-Moll, V. Solar district heating and cooling: A review. Int. J. Energy Res. 2018, 42, 1419-1441. [CrossRef]

13. Guelpa, E.; Verda, V. Thermal energy storage in district heating and cooling systems: A review. Appl. Energy 2019, $252,113474$. [CrossRef]

14. Buffa, S.; Cozzini, M.; D'Antoni, M.; Baratieri, M.; Fedrizzi, R. 5th generation district heating and cooling systems: A review of existing cases in Europe. Renew. Sustain. Energy Rev. 2019, 104, 504-522. [CrossRef]

15. Enescu, D.; Chicco, G.; Porumb, R.; Seritan, G. Thermal energy storage for grid applications: Current status and emerging trends. Energies 2020, 13, 340. [CrossRef]

16. Shabanpour-Haghighi, A.; Seifi, A.R. Effects of district heating networks on optimal energy flow of multi-carrier systems. Renew. Sustain. Energy Rev. 2016, 59, 379-387. [CrossRef]

17. Mirzaei, M.A.; Nazari-Heris, M.; Zare, K.; Mohammadi-Ivatloo, B.; Marzband, M.; Asadi, S.; Anvari-Moghaddam, A. Evaluating the impact of multi-carrier energy storage systems in optimal operation of integrated electricity, gas and district heating networks. Appl. Therm. Eng. 2020, 176, 115413. [CrossRef]

18. Geidl, M.; Andersson, G. Optimal power flow of multiple energy carriers. IEEE Trans. Power Syst. 2007, 22, 145-155. [CrossRef]

19. Krause, T.; Andersson, G.; Fröhlich, K.; Vaccaro, A. Multiple-Energy Carriers: Modeling of Production, Delivery, and Consumption. Proc. IEEE 2010, 99, 15-27. [CrossRef]

20. Favre-Perrod, P. A vision of future energy networks. In Proceedings of the IEEE Power Engineering Society Inaugural Conference and Exposition in Africa, Durban, South Africa, 11-15 July 2005.

21. European Commission. Final_Powering a Climate-Neutral Economy: An EU Strategy for Energy System Integration; European Commission: Brussels, Belgium, 2020.

22. Guelpa, E.; Bischi, A.; Verda, V.; Chertkov, M.; Lund, H. Towards future infrastructures for sustainable multi-energy systems: A review. Energy 2019, 184, 2-21. [CrossRef]

23. Levihn, F. CHP and heat pumps to balance renewable power production: Lessons from the district heating network in Stockholm. Energy 2017, 137, 670-678. [CrossRef]

24. Grohnheit, P.E. Modelling CHP within a national power system. Energy Policy 1993, 21, 418-429. [CrossRef]

25. Kavvadias, K.; Jimenez Navarro, J.P.; Quoilin, A.; Navarro, J. Case Study on the Impact of Cogeneration and Thermal Storage on the Flexibility of the Power System; European Commission: Brussels, Belgium, 2017; ISBN 9789279778087.

26. Jimenez-Navarro, J.P.; Kavvadias, K.; Filippidou, F.; Pavičević, M.; Quoilin, S. Coupling the heating and power sectors: The role of centralised combined heat and power plants and district heat in a European decarbonised power system. Appl. Energy 2020, 270, 115134. [CrossRef] 
27. Perez-Arriaga, I.J.; Batlle, C. Impacts of intermittent renewables on electricity generation system operation. Econ. Energy Environ. Policy 2012, 1, 3-17. [CrossRef]

28. Lew, D.; Brinkman, G.; Ibanez, E.; Florita, A.; Heaney, M.; Hodge, B.-M.; Hummon, M.; Stark, G.; King, N.J.; Lefton, R.S.A.; et al. The Western Wind and Solar Integration Study Phase 2; NREL (National Renewable Energy Laboratory): Golden, CO, USA, 2013; Available online: http:/ / www.osti.gov/bridge (accessed on 25 January 2021).

29. Böttger, D.; Götz, M.; Lehr, N.; Kondziella, H.; Bruckner, T. Potential of the Power-to-Heat technology in district heating grids in Germany. Energy Procedia 2014, 46, 246-253. [CrossRef]

30. Hedegaard, K.; Münster, M. Influence of individual heat pumps on wind power integration-Energy system investments and operation. Energy Convers. Manag. 2013, 75, 673-684. [CrossRef]

31. Papaefthymiou, G.; Hasche, B.; Nabe, C. Potential of heat pumps for demand side management and wind power integration in the German electricity market. IEEE Trans. Sustain. Energy 2012, 3, 636-642. [CrossRef]

32. Schaber, K.; Steinke, F.; Hamacher, T. Managing Temporary Oversupply from Renewables Efficiently: Electricity Storage Versus Energy Sector Coupling in Germany. In Proceedings of the 32nd Edition of the International Energy Workshop (IEW), Paris, France, 19-21 June 2013.

33. Kiviluoma, J.; Meibom, P. Influence of wind power, plug-in electric vehicles, and heat storages on power system investments. Energy 2010, 35, 1244-1255. [CrossRef]

34. Bloess, A.; Schill, W.P.; Zerrahn, A. Power-to-heat for renewable energy integration: A review of technologies, modeling approaches, and flexibility potentials. Appl. Energy 2018, 212, 1611-1626. [CrossRef]

35. Heinen, S.; Burke, D.; O'Malley, M. Electricity, gas, heat integration via residential hybrid heating technologies-An investment model assessment. Energy 2016, 109, 906-919. [CrossRef]

36. Werner, S. District Heating and Cooling. In Reference Module in Earth Systems and Environmental Sciences; Elsevier: Amsterdam, The Netherlands, 2013. Available online: https://www.diva-portal.org/smash/record.jsf?pid=diva2:676931 (accessed on 9 March 2021).

37. Margolis, A. Experiences with district heating in Europe and USA and its further development. J. Inst. Heat. Vent. Eng. 1935, 3, 361-413.

38. Brownlie, D. District heating in the United States and Russia. Engineering 1941, 152, $183-185$.

39. Lund, H.; Werner, S.; Wiltshire, R.; Svendsen, S.; Thorsen, J.E.; Hvelplund, F.; Mathiesen, B.V. 4th Generation District Heating (4GDH). Integrating smart thermal grids into future sustainable energy systems. Energy 2014, 68, 1-11. [CrossRef]

40. Ma, Z.; Knotzer, A.; Billanes, J.D.; Jørgensen, B.N. A literature review of energy flexibility in district heating with a survey of the stakeholders' participation. Renew. Sustain. Energy Rev. 2020, 123, 109750. [CrossRef]

41. González Juncà, A.; Rius Carrasco, A.; Riba Ruiz, J.-R. Environmental Engineering Combined Heat and Power Generation Systems for Optimum Environmental and Economic Performance: A Case Study in Catalonia. Ph.D. Thesis, Universitat Politècnica de Catalunya, Barcelona, Spain, 2016.

42. Mazhar, A.R.; Liu, S.; Shukla, A. A state of art review on the district heating systems. Renew. Sustain. Energy Rev. 2018, 96, 420-439. [CrossRef]

43. Fischer, D.; Madani, H. On heat pumps in smart grids: A review. Renew. Sustain. Energy Rev. 2017, 70, 342-357. [CrossRef]

44. Kinjyo, Y.; Palmer, M.D.; Yona, A.; Senjyu, T. Autonomous power system control by decentralized controllable loads. In Proceedings of the International Conference on Power Electronics and Drive Systems, Kitakyushu, Japan, 22-25 April 2013; pp. 881-886.

45. Brunner, M.; Tenbohlen, S.; Braun, M. Heat pumps as important contributors to local demand-side management. In Proceedings of the 2013 IEEE Grenoble Conference, Grenoble, France, 16-20 June 2013.

46. Bhattarai, B.P.; Bak-Jensen, B.; Pillai, J.R.; Maier, M. Demand flexibility from residential heat pump. In Proceedings of the IEEE Power and Energy Society General Meeting, National Harbor, MD, USA, 27-31 July 2014.

47. Wang, D.; Parkinson, S.; Miao, W.; Jia, H.; Crawford, C.; Djilali, N. Hierarchical market integration of responsive loads as spinning reserve. Appl. Energy 2013, 104, 229-238. [CrossRef]

48. Kirby, B.J. Spinning Reserve from Responsive Loads; Oak Ridge National Laboratory: Oak Ridge, TN, USA, 2003. Available online: https: / info.ornl.gov / sites/publications/Files/Pub57288.pdf (accessed on 9 January 2021).

49. Siano, P. Demand response and smart grids-A survey. Renew. Sustain. Energy Rev. 2014, 30, 461-478. [CrossRef]

50. Shariatzadeh, F.; Mandal, P.; Srivastava, A.K. Demand response for sustainable energy systems: A review, application and implementation strategy. Renew. Sustain. Energy Rev. 2015, 45, 343-350. [CrossRef]

51. Lund, P.D.; Lindgren, J.; Mikkola, J.; Salpakari, J. Review of energy system flexibility measures to enable high levels of variable renewable electricity. Renew. Sustain. Energy Rev. 2015, 45, 785-807. [CrossRef]

52. Biegel, B.; Andersen, P.; Stoustrup, J.; Madsen, M.B.; Hansen, L.H. Lumped thermal household model. In Proceedings of the 2013 4th IEEE/PES Innovative Smart Grid Technologies Europe, ISGT Europe 2013, Aalborg, Denmark, 7-9 October 2013.

53. Poulet, P.; Outbib, R. Energy production for dwellings by using hybrid systems based on heat pump variable input power. Appl. Energy 2015, 147, 413-429. [CrossRef]

54. Hong, J.; Johnstone, C.; Torriti, J.; Leach, M. Discrete demand side control performance under dynamic building simulation: A heat pump application. Renew. Energy 2012, 39, 85-95. [CrossRef] 
55. Williams, C.J.C.; Binder, J.O.; Kelm, T. Demand side management through heat pumps, thermal storage and battery storage to increase local self-consumption and grid compatibility of PV systems. In Proceedings of the 2012 3rd IEEE PES Innovative Smart Grid Technologies Europe (ISGT Europe), Berlin, Germany, 14-17 October 2012.

56. Dar, U.I.; Sartori, I.; Georges, L.; Novakovic, V. Advanced control of heat pumps for improved flexibility of Net-ZEB towards the grid. Energy Build. 2014, 69, 74-84. [CrossRef]

57. De Coninck, R.; Baetens, R.; Verbruggen, B.; Driesen, J.; Saelens, D.; Helsen, L. Modelling and simulation of a grid connected photovoltaic heat pump system with thermal energy storage using Modelica. In Proceedings of the 8th International Conference on Computational Methods in Systems Biology, Trento, Italy, 29 September-1 October 2010; p. 177.

58. Terreros, O.; Spreitzhofer, J.; Basciotti, D.; Schmidt, R.R.; Esterl, T.; Pober, M.; Kerschbaumer, M.; Ziegler, M. Electricity market options for heat pumps in rural district heating networks in Austria. Energy 2020, 196, 116875. [CrossRef]

59. Arteconi, A.; Hewitt, N.J.; Polonara, F. Domestic demand-side management (DSM): Role of heat pumps and thermal energy storage (TES) systems. Appl. Therm. Eng. 2013, 51, 155-165. [CrossRef]

60. Andreas, M. Adaptive Modellbasierte Prädiktive Regelung Einer Kleinwärmepumpenanlage; ETH Zürich: Zürich, Switzerland, 2006. [CrossRef]

61. Sichilalu, S.; Mathaba, T.; Xia, X. Optimal control of a wind-PV-hybrid powered heat pump water heater. Appl. Energy 2017, 185, 1173-1184. [CrossRef]

62. Wilfried, R. Regelung einer Wärmepumpenanlage mit Model Predictive Control; ETH Zürich: Zürich, Switzerland, 2004. [CrossRef]

63. Salpakari, J.; Lund, P. Optimal and rule-based control strategies for energy flexibility in buildings with PV. Appl. Energy 2016, 161, 425-436. [CrossRef]

64. Pedersen, T.S.; Andersen, P.; Nielsen, K.M. Central control of heat pumps for smart grid purposes tested on single family houses. In Proceedings of the 2013 10th IEEE International Conference on Networking, Sensing and Control (ICNSC), Evry, France, 10-12 April 2013; pp. 118-123.

65. Vrettos, E.; Lai, K.; Oldewurtel, F.; Andersson, G. Predictive Control of buildings for Demand Response with dynamic day-ahead and real-time prices. In Proceedings of the 2013 European Control Conference (ECC), Zürich, Switzerland, 17-19 July 2013; pp. 2527-2534.

66. Halvgaard, R.; Poulsen, N.K.; Madsen, H.; Jørgensen, J.B. Economic Model Predictive Control for building climate control in a Smart Grid. In Proceedings of the 2012 IEEE PES Innovative Smart Grid Technologies (ISGT), Washington, DC, USA, 16-20 January 2012.

67. Kajgaard, M.U.; Mogensen, J.; Wittendorff, A.; Veress, A.T.; Biegel, B. Model predictive control of domestic heat pump. In Proceedings of the Proceedings of the American Control Conference, Washington, DC, USA, 17-19 June 2013; pp. $2013-2018$.

68. Hirst, E.; Kirby, B. Electric-Power Ancillary Services; Oak Ridge National Laboratory: Oak Ridge, TN, USA, 1996.

69. Jóos, G.; Ooi, B.T.; McGillis, D.; Galiana, F.D.; Marceau, R. The potential of distributed generation to provide ancillary services. In Proceedings of the 2000 Power Engineering Society Summer Meeting (Cat. No.00CH37134), Seattle, WA, USA, 16-20 July 2000; Volume 3, pp. 1762-1767.

70. Dallmer-Zerbe, K.; Fischer, D.; Biener, W.; Wille-Haussmann, B.; Wittwer, C. Droop controlled operation of heat pumps on clustered distribution grids with high PV penetration. In Proceedings of the 2016 IEEE International Energy Conference (ENERGYCON), Leuven, Belgium, 4-8 April 2016.

71. Tanaka, K.; Yoza, A.; Ogimi, K.; Yona, A.; Senjyu, T.; Funabashi, T.; Kim, C.H. Optimal operation of DC smart house system by controllable loads based on smart grid topology. Renew. Energy 2012, 39, 132-139. [CrossRef]

72. Heat Pumps in District Heating and Cooling Systems-Final Report-HPT-Heat Pumping Technologies. Available online: https: //heatpumpingtechnologies.org/publications/heat-pumps-in-district-heating-and-cooling-systems-final-report/ (accessed on 14 January 2021).

73. Chen, X.; Lu, X.; McElroy, M.B.; Nielsen, C.P.; Kang, C. Synergies of wind power and electrified space heating: Case study for Beijing. Environ. Sci. Technol. 2014, 48, 2016-2024. [CrossRef]

74. Waite, M.; Modi, V. Potential for increased wind-generated electricity utilization using heat pumps in urban areas. Appl. Energy 2014, 135, 634-642. [CrossRef]

75. Sayegh, M.A.; Jadwiszczak, P.; Axcell, B.P.; Niemierka, E.; Bryś, K.; Jouhara, H. Heat pump placement, connection and operational modes in European district heating. Energy Build. 2018, 166, 122-144. [CrossRef]

76. Felten, B. An integrated model of coupled heat and power sectors for large-scale energy system analyses. Appl. Energy 2020, 266, 114521. [CrossRef]

77. Averfalk, H.; Ingvarsson, P.; Persson, U.; Gong, M.; Werner, S. Large heat pumps in Swedish district heating systems. Renew. Sustain. Energy Rev. 2017, 79, 1275-1284. [CrossRef]

78. Baldvinsson, I.; Nakata, T. A comparative exergy and exergoeconomic analysis of a residential heat supply system paradigm of Japan and local source based district heating system using SPECO (specific exergy cost) method. Energy 2014, 74, 537-554. [CrossRef]

79. Meesenburg, W.; Ommen, T.; Elmegaard, B. Dynamic exergoeconomic analysis of a heat pump system used for ancillary services in an integrated energy system. Energy 2018, 152, 154-165. [CrossRef]

80. Salehi, S.; Yari, M.; Rosen, M.A. Exergoeconomic comparison of solar-assisted absorption heat pumps, solar heaters and gas boiler systems for district heating in Sarein Town, Iran. Appl. Therm. Eng. 2019, 153, 409-425. [CrossRef] 
81. Schweiger, G.; Larsson, P.O.; Magnusson, F.; Lauenburg, P.; Velut, S. District heating and cooling systems-Framework for Modelica-based simulation and dynamic optimization. Energy 2017, 137, 566-578. [CrossRef]

82. Barone, G.; Buonomano, A.; Forzano, C.; Palombo, A. A novel dynamic simulation model for the thermo-economic analysis and optimisation of district heating systems. Energy Convers. Manag. 2020, 220, 113052. [CrossRef]

83. Connolly, D.; Lund, H.; Mathiesen, B.V.; Werner, S.; Möller, B.; Persson, U.; Boermans, T.; Trier, D.; Østergaard, P.A.; Nielsen, S. Heat Roadmap Europe: Combining district heating with heat savings to decarbonise the EU energy system. Energy Policy 2013, 65, 475-489. [CrossRef]

84. Strbac, G.; Pudjianto, D.; Sansom, R.; Djapic, P.; Ameli, H.; Shah, N.; Brandon, N.; Hawkes, A. Analysis of Alternative UK Heat Decarbonisation Pathways; Imperial College London: London, UK, 2018.

85. Blarke, M.B. Towards an intermittency-friendly energy system: Comparing electric boilers and heat pumps in distributed cogeneration. Appl. Energy 2012, 91, 349-365. [CrossRef]

86. Olmos, L.; Cossent, R.; Lobato, E.; Gómez, T. Barriers to the implementation of response options aimed at mitigating the impact of wind power on electricity systems. Wind Energy 2011, 14, 781-795. [CrossRef]

87. Bolkesjo, T.F.; Kirkerud, J.G.; Tromborg, E. Power market impacts of increased use of electricity in the heating sector. In Proceedings of the 2017 14th International Conference on the European Energy Market (EEM), Dresden, Germany, 6-9 June 2017. [CrossRef]

88. Rehfeldt, M.; Fleiter, T.; Toro, F. A bottom-up estimation of the heating and cooling demand in European industry. Energy Effic. 2017, 11, 1057-1082. [CrossRef]

89. UNFCCC. Adoption of the Paris Agreement_Paris Agreement Text English; UNFCCC: Bonn, Germany, 2015.

90. Energy Communities-Energy. Available online: https://ec.europa.eu/energy/topics/markets-and-consumers/energycommunities_en (accessed on 22 July 2021).

91. Clean Energy for All Europeans Package-Energy. Available online: https://ec.europa.eu/energy/topics/energy-strategy/ clean-energy-all-europeans_en (accessed on 22 July 2021).

92. Caroni, P. Position Paper Smart Sector Integration, towards EU System of Systems Building Blocks, Enablers, Architectures, Regulatory Barriers, Economic Assessment; ETIP SNET: Brussels, Belgium, 2021.

93. Rinaldi, A.; Soini, M.C.; Streicher, K.; Patel, M.K.; Parra, D. Decarbonising heat with optimal PV and storage investments: A detailed sector coupling modelling framework with flexible heat pump operation. Appl. Energy 2021, 282, 116110. [CrossRef]

94. Smart Grids and Smart Meters-Energy Transition-The Wiki. Available online: http://wiki.energytransition.org/wiki/smartgrids-and-smart-meters / (accessed on 23 July 2021).

95. Martorana, F.; Bonomolo, M.; Leone, G.; Monteleone, F.; Zizzo, G.; Beccali, M. Solar-assisted heat pumps systems for domestic hot water production in small energy communities. Sol. Energy 2021, 217, 113-133. [CrossRef]

96. The Lights Will Stay on in Europe with 50 Million Heat Pumps. Available online: https://heatpumpingtechnologies.org/news/ $1 / 56037$ (accessed on 23 July 2021).

97. Palomba, V.; Gasia, J.; Romaní, J.; Frazzica, A.; Cabeza, L.F. Definition of Performance Indicators for Thermal Energy Storage. In Recent Advancements in Materials and Systems for Thermal Energy Storage-An Introduction to Experimental Characterization Methods; Frazzica, A., Cabeza, L.F., Eds.; Springer: Berlin/Heidelberg, Germany, 2019; pp. 227-242. ISBN 978-3-319-96640-3.

98. Nazir, H.; Batool, M.; Bolivar Osorio, F.J.; Isaza-Ruiz, M.; Xu, X.; Vignarooban, K.; Phelan, P.; Kannan, A.M. Recent developments in phase change materials for energy storage applications: A review. Int. J. Heat Mass Transf. 2019, 129, 491-523. [CrossRef]

99. Hennessy, J.; Li, H.; Wallin, F.; Thorin, E. Flexibility in thermal grids: A review of short-term storage in district heating distribution networks. Energy Procedia 2019, 158, 2430-2434. [CrossRef]

100. Cabeza, L.F.; Palomba, V. The Role of Thermal Energy Storage in the Energy System; Elsevier: Amsterdam, The Netherlands, 2020.

101. Dalla Rosa, A.; Christensen, J.E. Low-energy district heating in energy-efficient building areas. Energy 2011, 36, 6890-6899. [CrossRef]

102. Arce, P.; Medrano, M.; Gil, A.; Oró, E.; Cabeza, L.F. Overview of thermal energy storage (TES) potential energy savings and climate change mitigation in Spain and Europe. Appl. Energy 2011, 88, 2764-2774. [CrossRef]

103. Romanchenko, D.; Kensby, J.; Odenberger, M.; Johnsson, F. Thermal energy storage in district heating: Centralised storage vs. storage in thermal inertia of buildings. Energy Convers. Manag. 2018, 162, 26-38. [CrossRef]

104. Olsthoorn, D.; Haghighat, F.; Mirzaei, P.A. Integration of storage and renewable energy into district heating systems: A review of modelling and optimization. Sol. Energy 2016, 136, 49-64. [CrossRef]

105. Eriksson, R. Heat storages in Swedish district heating systems an analysis of the installed thermal energy storage capacity. Master's Thesis, Halmstad University, Halmstad, Sweden, 2016.

106. Basciotti, D.; Judex, F.; Pol, O.; Schmidt, R.-R. Sensible Heat Storage in District Heating Networks: A Novel Control Strategy Using the Network as Storage. In Proceedings of the 6th International Renewable Energy Storage Conference IRES, Berlin, Germany, 28-30 November 2011.

107. Frazzica, A.; Manzan, M.; Sapienza, A.; Freni, A.; Toniato, G.; Restuccia, G. Experimental testing of a hybrid sensible-latent heat storage system for domestic hot water applications. Appl. Energy 2016, 183, 1157-1167. [CrossRef]

108. Chan, A.L.S.; Chow, T.T.; Fong, S.K.F.; Lin, J.Z. Performance evaluation of district cooling plant with ice storage. Energy 2006, 31, 2750-2762. [CrossRef] 
109. He, B.; Rydstrand, M.; Martin, V.; Setterwall, F. Designing paraffin waxes phase change material (PCM) cool storage system for peak shaving in district cooling system. In Proceedings of the 1st International Energy Conversion Engineering Conference IECEC17, Portsmouth, VA, USA, 17-21 August 2003.

110. Renewable Energy Agency Irena. Innovation Outlook Thermal Energy Storage About Irena. 2020. Available online: https: //www.irena.org/ (accessed on 13 July 2021).

111. Xu, J.; Wang, R.Z.; Li, Y. A review of available technologies for seasonal thermal energy storage. Sol. Energy 2014, 103, 610-638. [CrossRef]

112. Sorknæs, P. Simulation method for a pit seasonal thermal energy storage system with a heat pump in a district heating system. Energy 2018, 152, 533-538. [CrossRef]

113. Vanhoudt, D.; Desmedt, J.; van Bael, J.; Robeyn, N.; Hoes, H. An aquifer thermal storage system in a Belgian hospital: Long-term experimental evaluation of energy and cost savings. Energy Build. 2011, 43, 3657-3665. [CrossRef]

114. Chwieduk, D.A. Solar-Assisted Heat Pumps. Available online: https://scholar.google.com/scholar_lookup?title=Solarassistedheatpumps\&publication_year=2012\&author=DAChwieduk (accessed on 9 September 2021).

115. Harris, M.; Peck, P.; Backman, M. Thermal Energy Storage in Sweden and Denmark Potentials for Technology Transfer. Master's Thesis, Lund University, Lund, Sweden, 2011.

116. Mangold, D.; Deschaintre, L. Seasonal Thermal Energy Storage: Report on State of the Art and Necessary Further R + D. In IEA SHC Task 45; SHC: Zealand, Denmark, 2015. Available online: https:/ / www.solites.de/ (accessed on 9 September 2021).

117. Lanahan, M.; Tabares-Velasco, P.C. Seasonal Thermal-Energy Storage: A Critical Review on BTES Systems, Modeling, and System Design for Higher System Efficiency. Energies 2017, 10, 743. [CrossRef]

118. Nam, Y.J.; Gao, X.Y.; Yoon, S.H.; Lee, K.H. Study on the Performance of a Ground Source Heat Pump System Assisted by Solar Thermal Storage. Energies 2015, 8, 13378-13394. [CrossRef]

119. Farulla, G.A.; Cellura, M.; Guarino, F.; Ferraro, M. A Review of Thermochemical Energy Storage Systems for Power Grid Support. Appl. Sci. 2020, 10, 3142. [CrossRef]

120. N'Tsoukpoe, K.E.; Liu, H.; Le Pierrès, N.; Luo, L. A review on long-term sorption solar energy storage. Renew. Sustain. Energy Rev. 2009, 13, 2385-2396. [CrossRef]

121. Hui, L.; Edem, N.K.; Nolwenn, L.P.; Luo, L. Evaluation of a seasonal storage system of solar energy for house heating using different absorption couples. Energy Convers. Manag. 2011, 52, 2427-2436. [CrossRef]

122. Hauer, A. Thermal energy storage with zeolite for heating and cooling applications. In Proceedings of the International Sorption Heat Pump Conference, Shanghai, China, 24-27 September 2002. Available online: http://hpc.01.free.fr/papers/vol2/hpc01_69 .pdf (accessed on 9 February 2021).

123. Steinmann, W.D.; Bauer, D.; Jockenhöfer, H.; Johnson, M. Pumped thermal energy storage (PTES) as smart sector-coupling technology for heat and electricity. Energy 2019, 183, 185-190. [CrossRef]

124. Cammarata, A.; Verda, V.; Sciacovelli, A.; Ding, Y. Hybrid strontium bromide-natural graphite composites for low to medium temperature thermochemical energy storage: Formulation, fabrication and performance investigation. Energy Convers. Manag. 2018, 166, 233-240. [CrossRef]

125. Ferrucci, F.; Stitou, D.; Ortega, P.; Lucas, F. Mechanical compressor-driven thermochemical storage for cooling applications in tropical insular regions. Concept and efficiency analysis. Appl. Energy 2018, 219, 240-255. [CrossRef]

126. Fitó, J.; Coronas, A.; Mauran, S.; Mazet, N.; Perier-Muzet, M.; Stitou, D. Hybrid system combining mechanical compression and thermochemical storage of ammonia vapor for cold production. Energy Convers. Manag. 2019, 180, 709-723. [CrossRef]

127. Palomba, V.; Borri, E.; Charalampidis, A.; Frazzica, A.; Cabeza, L.F.; Karellas, S. Implementation of a solar-biomass system for multi-family houses: Towards 100\% renewable energy utilization. Renew. Energy 2020, 166, 190-209. [CrossRef]

128. Palomba, V.; Borri, E.; Charalampidis, A.; Frazzica, A.; Karellas, S.; Cabeza, L.F. An Innovative Solar-Biomass Energy System to Increase the Share of Renewables in Office Buildings. Energies 2021, 14, 914. [CrossRef]

129. Guelpa, E.; Toro, C.; Sciacovelli, A.; Melli, R.; Sciubba, E.; Verda, V. Optimal operation of large district heating networks through fast fluid-dynamic simulation. Energy 2016, 102, 586-595. [CrossRef]

130. Tveit, T.M.; Savola, T.; Gebremedhin, A.; Fogelholm, C.J. Multi-period MINLP model for optimising operation and structural changes to CHP plants in district heating networks with long-term thermal storage. Energy Convers. Manag. 2009, 50, 639-647. [CrossRef]

131. Gustafsson, S.I.; Karlsson, B.G. Heat accumulators in CHP networks. Energy Convers. Manag. 1992, 33, 1051-1061. [CrossRef]

132. Ramm, T.; Hammel, C.; Klärner, M.; Kruck, A.; Schrag, T. Energy storage and integrated energy approach for district heating systems. Energy Procedia 2017, 135, 391-397. [CrossRef]

133. Rong, A.; Lahdelma, R. Role of polygeneration in sustainable energy system development challenges and opportunities from optimization viewpoints. Renew. Sustain. Energy Rev. 2016, 53, 363-372. [CrossRef]

134. Scapino, L.; Zondag, H.A.; Van Bael, J.; Diriken, J.; Rindt, C.C.M. Sorption heat storage for long-term low-temperature applications: A review on the advancements at material and prototype scale. Appl. Energy 2017, 190, 920-948. [CrossRef]

135. Jones, B.W.; Powell, R. Evaluation of distributed building thermal energy storage in conjunction with wind and solar electric power generation. Renew. Energy 2015, 74, 699-707. [CrossRef]

136. Thermal Energy Storage: Technology Brief. Available online: https://www.irena.org/publications/2013/Jan/Thermal-energystorage (accessed on 9 February 2021). 
137. Colmenar-Santos, A.; Borge-Díez, D.; Rosales-Asensio, E. District Heating and Cooling Networks in the European Union; Springer: Berlin/Heidelberg, Germany, 2017.

138. Rech, S.; Lazzaretto, A. Smart rules and thermal, electric and hydro storages for the optimum operation of a renewable energy system. Energy 2018, 147, 742-756. [CrossRef]

139. Desrues, T.; Ruer, J.; Marty, P.; Fourmigué, J.F. A thermal energy storage process for large scale electric applications. Appl. Therm. Eng. 2010, 30, 425-432. [CrossRef]

140. Wang, L.; Lin, X.; Zhang, H.; Peng, L.; Chen, H. Brayton-cycle-based pumped heat electricity storage with innovative operation mode of thermal energy storage array. Appl. Energy 2021, 291, 116821. [CrossRef]

141. Dumont, O.; Frate, G.F.; Pillai, A.; Lecompte, S.; De paepe, M.; Lemort, V. Carnot battery technology: A state-of-the-art review. J. Energy Storage 2020, 32, 101756. [CrossRef]

142. Nuytten, T.; Claessens, B.; Paredis, K.; Van Bael, J.; Six, D. Flexibility of a combined heat and power system with thermal energy storage for district heating. Appl. Energy 2013, 104, 583-591. [CrossRef]

143. Haeseldonckx, D.; Peeters, L.; Helsen, L.; D'haeseleer, W. The impact of thermal storage on the operational behaviour of residential $\mathrm{CHP}$ facilities and the overall $\mathrm{CO}_{2}$ emissions. Renew. Sustain. Energy Rev. 2007, 11, 1227-1243. [CrossRef]

144. Al-Qattan, A.; Elsherbini, A.; Al-Ajmi, K. Solid oxide fuel cell application in district cooling. J. Power Sources 2014, $257,21-26$. [CrossRef]

145. Verda, V.; Colella, F. Primary energy savings through thermal storage in district heating networks. Energy 2011, 36, 4278-4286. [CrossRef]

146. Palomba, V.; Frazzica, A. Comparative analysis of thermal energy storage technologies through the definition of suitable key performance indicators. Energy Build. 2019, 185, 88-102. [CrossRef]

147. Sector Coupling. Creating an interconnected Decarbonized Energy System Benefiting Industry, the Power Sector and Society; Springer: Cham, The Netherlands, 2020.

148. Power System Flexibility for the Energy Transition. Available online: https:/ /www.irena.org/publications/2018/Nov/Powersystem-flexibility-for-the-energy-transition (accessed on 3 November 2021).

149. Power Supply and Transport Benefit from Sector Coupling. Available online: https://www.agora-verkehrswende.de/en/12 -insights / power-supply-and-transport-benefit-from-sector-coupling/ (accessed on 3 November 2021). 